Cite this: Dalton Trans., 2014, 43, 9557

\section{Soft diphosphine and diarsine complexes of niobium(v) and tantalum(v) fluorides: synthesis, properties, structures and comparisons with the corresponding chlorides $\dagger$}

\begin{abstract}
William Levason, * Mark. E. Light, Gillian Reid and Wenjian Zhang
The reactions of the soft diphosphines $0-\mathrm{C}_{6} \mathrm{H}_{4}\left(\mathrm{PMe}_{2}\right)_{2}, \mathrm{Me}_{2} \mathrm{P}\left(\mathrm{CH}_{2}\right)_{2} \mathrm{PMe}_{2}, \mathrm{Et}_{2} \mathrm{P}\left(\mathrm{CH}_{2}\right)_{2} \mathrm{PEt}_{2}$ or $O-\mathrm{C}_{6} \mathrm{H}_{4}\left(\mathrm{PPh}_{2}\right)_{2}$ with $\mathrm{NbF}_{5}$ or $\mathrm{TaF}_{5}$ in anhydrous $\mathrm{MeCN}$ solution produce $\left.\left[\mathrm{MF}_{4} \text { (diphosphine }\right)_{2}\right]\left[\mathrm{MF}_{6}\right](\mathrm{M}=\mathrm{Nb}$ or Ta), which have been characterised by microanalysis, IR, ${ }^{1} \mathrm{H},{ }^{19} \mathrm{~F}\left\{{ }^{1} \mathrm{H}\right\},{ }^{31} \mathrm{P}\left\{{ }^{1} \mathrm{H}\right\}$ and ${ }^{93} \mathrm{Nb} N M R$ spectroscopy. X-ray crystal structures are reported for the isomorphous $\left[\mathrm{MF}_{4}\left\{\mathrm{O}-\mathrm{C}_{6} \mathrm{H}_{4}\left(\mathrm{PMe}_{2}\right)_{2}\right\}_{2}\right]\left[\mathrm{MF}_{6}\right]$, which confirm the presence of eight-coordinate (distorted dodecahedral) cations. The corresponding reactions using $\mathrm{O}-\mathrm{C}_{6} \mathrm{H}_{4}\left(\mathrm{AsMe}_{2}\right)_{2}$ produced $\left[\mathrm{MF}_{4}\left\{\mathrm{O}-\mathrm{C}_{6} \mathrm{H}_{4}\left(\mathrm{AsMe}_{2}\right)_{2}\right\}_{2}\right]\left[\mathrm{MF}_{6}\right]$ which were similarly characterised, including by the $\mathrm{X}$-ray structure of $\left[\mathrm{NbF}_{4}\left\{\mathrm{O}-\mathrm{C}_{6} \mathrm{H}_{4}\left(\mathrm{AsMe}_{2}\right)_{2}\right\}_{2}\right]\left[\mathrm{NbF}_{6}\right]$. These are very rare examples of arsine complexes of high valent metal fluorides. The chloro complexes $\left[\mathrm{NbCl}_{4}\left\{\mathrm{O}-\mathrm{C}_{6} \mathrm{H}_{4}\left(\mathrm{PMe}_{2}\right)_{2}\right\}_{2}\right] \mathrm{Cl},\left[\mathrm{TaCl}_{4}\{\mathrm{O}-\right.$ $\left.\left.\mathrm{C}_{6} \mathrm{H}_{4}\left(\mathrm{PMe}_{2}\right)_{2}\right\}_{2}\right]\left[\mathrm{TaCl}_{6}\right],\left[\mathrm{NbCl}_{4}\left\{\mathrm{Me}_{2} \mathrm{P}\left(\mathrm{CH}_{2}\right)_{2} \mathrm{PMe}_{2}\right\}_{2}\right]\left[\mathrm{NbCl}_{6}\right]$ and $\left[\mathrm{MCl}_{4}\left\{\mathrm{O}-\mathrm{C}_{6} \mathrm{H}_{4}\left(\mathrm{AsMe}_{2}\right)_{2}\right\}_{2}\right]\left[\mathrm{MCl}_{6}\right]$ were prepared and their structural and spectroscopic properties compared with the fluoride analogues. Attempts to prepare diphosphine complexes of $\mathrm{NbOF}_{3}$ were unsuccessful, but the $\mathrm{NbOCl}_{3}$ complexes, $\left[\left\{\left\{\mathrm{Me}_{2} \mathrm{P}\right.\right.\right.$ $\left.\left.\left.\left(\mathrm{CH}_{2}\right)_{2} \mathrm{PMe}_{2}\right\} \mathrm{NbOCl}_{3}\right\}_{2}\left\{\mu-\mathrm{Me}_{2} \mathrm{P}\left(\mathrm{CH}_{2}\right)_{2} \mathrm{PMe}_{2}\right\}\right]$ and $\quad\left[\mathrm{OO}_{6} \mathrm{C}_{6} \mathrm{H}_{4}\left(\mathrm{PMe}_{2}\right)_{2}\right\} \mathrm{NbOCl}_{3}(\mu-\mathrm{O}) \mathrm{NbCl}_{3}\left(\mathrm{CH}_{3} \mathrm{CN}\right)\{\mathrm{O}-$ $\left.\left.\mathrm{C}_{6} \mathrm{H}_{4}\left(\mathrm{PMe}_{2}\right)_{2}\right\}\right]$ were obtained. X-Ray structures are also reported for $\left[\mathrm{NbCl}_{4}\left\{\mathrm{O}-\mathrm{C}_{6} \mathrm{H}_{4}\left(\mathrm{PMe}_{2}\right)_{2}\right\}_{2}\right] \mathrm{Cl}$, $\left[\mathrm{NbCl}_{4}\left\{\mathrm{O}-\mathrm{C}_{6} \mathrm{H}_{4}\left(\mathrm{AsMe}_{2}\right)_{2}\right\}_{2}\right]\left[\mathrm{NbCl}{ }_{5}(\mathrm{OEt})\right], \quad\left[\mathrm{NbCl}_{4}\left\{\mathrm{O}-\mathrm{C}_{6} \mathrm{H}_{4}\left(\mathrm{PMe}_{2}\right)_{2}\right\}_{2}\right]\left[\mathrm{NbOCl}_{4}\left(\mathrm{CH}_{3} \mathrm{CN}\right)\right]$, [\{ $\left\{\mathrm{Me}_{2} \mathrm{P}\left(\mathrm{CH}_{2}\right)_{2} \mathrm{PMe}_{2}\right\}-$ $\left.\left.\mathrm{NbOCl}_{3}\right\}_{2}\left\{\mu-\mathrm{Me}_{2} \mathrm{P}\left(\mathrm{CH}_{2}\right)_{2} \mathrm{PMe}_{2}\right\}\right]$ and $\left[\left\{\mathrm{O}-\mathrm{C}_{6} \mathrm{H}_{4}\left(\mathrm{PMe}_{2}\right)_{2}\right\} \mathrm{NbOCl}_{3}(\mu-\mathrm{O}) \mathrm{NbCl}_{3}\left(\mathrm{CH}_{3} \mathrm{CN}\right)\left\{\mathrm{O}-\mathrm{C}_{6} \mathrm{H}_{4}\left(\mathrm{PMe}_{2}\right)_{2}\right\}\right]$.
\end{abstract}

Received 7th April 2014, Accepted 2nd May 2014

DOI: $10.1039 / c 4 d t 01029 a$

www.rsc.org/dalton range of adducts with O-donor Lewis bases have been thoroughly characterised, and in addition to simple adduct formation, $\mathrm{C}-\mathrm{O}, \mathrm{C}-\mathrm{H}$ or $\mathrm{C}-\mathrm{C}$ bond cleavage, rearrangements and polymerisation reactions have been observed. ${ }^{3-5}$ A smaller range of N-donor adducts are also known. ${ }^{3-5}$ As would be expected for very hard Lewis acids, complexes with soft Lewis bases are rare. We have reported extremely moisture sensitive thioether complexes of types $\left[\mathrm{MF}_{5}\left(\mathrm{SR}_{2}\right)\right](\mathrm{M}=\mathrm{Nb}$ or $\mathrm{Ta})$, $\left[\mathrm{MF}_{4}\left(\mathrm{SR}_{2}\right)_{4}\right]\left[\mathrm{MF}_{6}\right]$ and $\left[\mathrm{MF}_{4}\left\{\mathrm{RS}\left(\mathrm{CH}_{2}\right) \mathrm{SR}_{2}\right]\left[\mathrm{MF}_{6}\right]\right.$; the last two types contain eight-coordinate cations. ${ }^{6,7}$ Unstable complexes with selenoethers also form, but these decompose in a few hours with fluorination of the ligand. ${ }^{6,7}$ There appear to be no characterised examples of these pentafluorides complexed to neutral phosphorus or arsenic ligands. ${ }^{3}$ The heavier halides $\mathrm{MX}_{5}(\mathrm{X}=\mathrm{Cl}$ or $\mathrm{Br})$ are also strong Lewis acids which form many complexes with both hard and soft donor ligands, including P- or As-donor ligands. ${ }^{8}$ It is notable that hydrolysis of the adducts with the heavier halides, or sometimes $\mathrm{O}$-abstraction from neutral ligands, results in oxide-halide complexes, ${ }^{5,8,9}$ whereas similar $\mathrm{O} / \mathrm{F}$ exchange does not occur with the pentafluorides. ${ }^{3,4}$ Complexes of $\mathrm{NbOF}_{3}$ were reported very recently, formed by reaction of $\mathrm{MF}_{5}$, hard donor ligands including $\mathrm{OPR}_{3}, \mathrm{OSMe}_{2}, 2,2$ '-bipyridyl or 1,10-phenanthroline, 
and the siloxane $\left(\mathrm{Me}_{3} \mathrm{Si}\right)_{2} \mathrm{O}$ (HMDSO) ${ }^{5}$ although the tantalum analogues remain unknown. Here we report the synthesis of complexes of $\mathrm{NbF}_{5}$ and $\mathrm{TaF}_{5}$ with diphosphine and diarsine ligands, attempts to make $\mathrm{NbOF}_{3}$ adducts, and comparable data on complexes with $\mathrm{NbCl}_{5}, \mathrm{TaCl}_{5}$ and $\mathrm{NbOCl}_{3}$.

\section{Results and discussion}

\section{$\left[\mathrm{MF}_{4}(\text { diphosphine })_{2}\right]\left[\mathrm{MF}_{6}\right]$ complexes}

Initial attempts to form complexes of alkyldiphosphines (L-L) $\left(\mathrm{L}-\mathrm{L}=o-\mathrm{C}_{6} \mathrm{H}_{4}\left(\mathrm{PMe}_{2}\right)_{2}, \mathrm{Me}_{2} \mathrm{P}\left(\mathrm{CH}_{2}\right)_{2} \mathrm{PMe}_{2}\right.$ or $\left.\mathrm{Et}_{2} \mathrm{P}\left(\mathrm{CH}_{2}\right)_{2} \mathrm{PEt}_{2}\right)$ used reaction of the appropriate $\mathrm{MF}_{5}$ with the diphosphine in anhydrous $\mathrm{CH}_{2} \mathrm{Cl}_{2}$ solution, similar conditions to those used to make thioether complexes, ${ }^{6,7}$ and diphosphine complexes of $\mathrm{TiF}_{4}$ from $\left[\mathrm{TiF}_{4}(\mathrm{MeCN})_{2}\right] .{ }^{10}$ However, this approach failed; the major products were phosphonium salts of the well known $\left[\mathrm{MF}_{6}\right]^{-}$anions, and some other unidentified species. It is likely that the $\mathrm{CH}_{2} \mathrm{Cl}_{2}$ is activated towards reaction with the phosphines by the strong Lewis acidity of the pentafluorides. In contrast, reaction of $\mathrm{MF}_{5}$ with the diphosphines in anhydrous MeCN gave colourless solutions, which on concentration or precipitation with anhydrous diethyl ether, deposited $\left[\mathrm{MF}_{4}{ }^{-}\right.$ $\left.(\mathrm{L}-\mathrm{L})_{2}\right]\left[\mathrm{MF}_{6}\right]$ as white microcrystalline powders, except for $\left[\mathrm{TaF}_{4}\left\{\mathrm{Et}_{2} \mathrm{P}\left(\mathrm{CH}_{2}\right)_{2} \mathrm{PEt}_{2}\right\}_{2}\right]\left[\mathrm{TaF}_{6}\right]$, which was a waxy solid. The complexes $\left[\mathrm{MF}_{4}\left\{0-\mathrm{C}_{6} \mathrm{H}_{4}\left(\mathrm{PPh}_{2}\right)_{2}\right\}_{2}\right]\left[\mathrm{MF}_{6}\right]$ formed similarly, but $\mathrm{PMe}_{3}$ did not react cleanly with the $\mathrm{MF}_{5}$ in anhydrous MeCN, the isolated products containing substantial amounts of coordinated nitrile (IR and ${ }^{1} \mathrm{H}$ NMR spectroscopic evidence) as well as some $\mathrm{PMe}_{3}$. The $\left[\mathrm{MF}_{5}\right]_{4}$ dissolve in $\mathrm{MeCN}$ with formation of $\left[\mathrm{MF}_{4}(\mathrm{MeCN})_{4}\right]\left[\mathrm{MF}_{6}\right],{ }^{4 g}$ which may be intermediates in the reactions; however since $\left[\mathrm{MF}_{4}\left(\mathrm{RS}\left(\mathrm{CH}_{2}\right)_{2} \mathrm{SR}\right)_{2}\right]\left[\mathrm{MF}_{6}\right]$ form from reaction of $\mathrm{MF}_{5}$ with $\mathrm{RS}\left(\mathrm{CH}_{2}\right)_{2} \mathrm{SR}$ in $\mathrm{CH}_{2} \mathrm{Cl}_{2},{ }^{6,7}$ a donor solvent is not essential to break up the tetrameric pentafluorides. It seems that the soft $\mathrm{PMe}_{3}$ cannot compete successfully with the hard MeCN for the metal centres, at least when the nitrile is present in large excess as solvent (whilst use of chlorocarbon solvents is ruled out by the reactivity described above). Note that $\mathrm{PMe}_{3}$ also failed to cleanly displace MeCN from $\left[\mathrm{TiF}_{4}(\mathrm{MeCN})_{2}\right]{ }^{10}$ Several chloride analogues, $\left[\mathrm{NbCl}_{4}\{o-\right.$ $\left.\left.\mathrm{C}_{6} \mathrm{H}_{4}\left(\mathrm{PMe}_{2}\right)_{2}\right\}_{2}\right] \mathrm{Cl},\left[\mathrm{TaCl}_{4}\left\{o-\mathrm{C}_{6} \mathrm{H}_{4}\left(\mathrm{PMe}_{2}\right)_{2}\right\}_{2}\right]\left[\mathrm{TaCl}_{6}\right]$ and $\left[\mathrm{NbCl}_{4}-\right.$ $\left.\left\{\mathrm{Me}_{2} \mathrm{P}\left(\mathrm{CH}_{2}\right)_{2} \mathrm{PMe}_{2}\right\}_{2}\right]\left[\mathrm{NbCl}_{6}\right]$ were made for comparison purposes from reaction of the corresponding $\mathrm{MCl}_{5}$ with the diphosphine in anhydrous MeCN. The structure of $\left[\mathrm{TaCl}_{4}\left\{\mathrm{Me}_{2} \mathrm{P}-\right.\right.$ $\left.\left.\left(\mathrm{CH}_{2}\right)_{2} \mathrm{PMe}_{2}\right\}_{2}\right]^{+}$has also been reported. ${ }^{11}$ The niobium chloro complexes are orange, while those with tantalum are white or pale yellow.

The diphosphine complexes of the metal fluorides are moisture sensitive solids, modestly soluble in anhydrous MeCN, in which they retain their integrity (NMR evidence see below), although they decompose in $\mathrm{CH}_{2} \mathrm{Cl}_{2}$, and are very readily hydrolysed in solution. Hydrolysis produces a mixture of free diphosphine and the phosphonium hexafluorometallate(v), e.g. $\left[\mathrm{Me}_{2} \mathrm{P}\left(\mathrm{CH}_{2}\right)_{2} \mathrm{PMe}_{2} \mathrm{H}\right]\left[\mathrm{NbF}_{6}\right]$ from $\left[\mathrm{NbF}_{4}\left\{\mathrm{Me}_{2} \mathrm{P}-\right.\right.$ $\left.\left.\left(\mathrm{CH}_{2}\right)_{2} \mathrm{PMe}_{2}\right\}_{2}\right]\left[\mathrm{NbF}_{6}\right]$, identified by their characteristic NMR spectra. The chloro-complexes are less moisture sensitive and generally poorly soluble in non- or weakly coordinating solvents.

It is convenient to discuss the X-ray structures first and then interpret the spectroscopy and reactions in terms of the complex units present. The two diphosphine complexes $\left[\mathrm{MF}_{4}\left\{o-\mathrm{C}_{6} \mathrm{H}_{4}\left(\mathrm{PMe}_{2}\right)_{2}\right\}_{2}\right]\left[\mathrm{MF}_{6}\right](\mathrm{M}=\mathrm{Nb}$ or Ta) are isomorphous (Table 1) and contain eight coordinate distorted dodecahedral cations and the familiar octahedral anions. The cation geometries (Fig. 1 and 2) show essentially identical M-F and M-P distances for the two metal centres, with the former slightly longer (by $\sim 0.07 \AA$ ) than those found in the $\left[\mathrm{MF}_{6}\right]^{-}$anions. In part this can be attributed to the increase in coordination number, but it is notable that the $d(\mathrm{M}-\mathrm{F})$ in the cations are longer (by $\sim 0.02 \AA$ ) than those found in the eightcoordinate cations in $\left[\mathrm{MF}_{4}\left\{\mathrm{RS}\left(\mathrm{CH}_{2}\right)_{2} \mathrm{SR}_{2}\right]^{+}\right.$or $\left[\mathrm{MF}_{4}\{\mathrm{MeO}-\right.$ $\left.\left.\left(\mathrm{CH}_{2}\right)_{2} \mathrm{OMe}\right\}_{2}\right]^{+},{ }^{4 b, 6,7}$ possibly indicating some steric crowding by the phosphorus centres which carry three substituents, as against two in the Group 16 donor ligands. Comparison of the cation geometry in $\left[\mathrm{NbCl}_{4}\left\{o-\mathrm{C}_{6} \mathrm{H}_{4}\left(\mathrm{PMe}_{2}\right)_{2}\right\}_{2}\right] \mathrm{Cl}$ (Fig. 3) with those in the fluorides shows $d(\mathrm{Nb}-\mathrm{P})$ has increased by $\sim 0.04 \AA$, which could be due to steric crowding, but may also reflect weaker Lewis acidity of the tetrachloroniobium(v) centre compared to the fluoride analogue.

The IR spectra of the $\left[\mathrm{MF}_{4}(\mathrm{~L}-\mathrm{L})_{2}\right]\left[\mathrm{MF}_{6}\right]$ show the presence of the L-L, the absence of phosphine oxide groups, and strong overlapping features in the range $620-550 \mathrm{~cm}^{-1}$ assigned as terminal M-F stretching vibrations. ${ }^{5-7}$ The ${ }^{1} \mathrm{H}$ NMR spectra (Experimental section) show the expected resonances for the neutral ligand, shifted to high frequency on coordination. In the diphosphine complexes ${ }^{2} J_{\mathrm{PH}}$ couplings were usually not clearly resolved. Multinuclear NMR spectra $\left({ }^{19} \mathrm{~F},{ }^{31} \mathrm{P}\right)$ are much more informative. The ${ }^{19} \mathrm{~F}\left\{{ }^{1} \mathrm{H}\right\}$ NMR spectra in MeCN solution at ambient temperatures show the characteristic 10 line multiplet at $\delta=+103 \mathrm{ppm}$ for $\left[\mathrm{NbF}_{6}\right]^{-}$and a singlet at $\delta=+38 \mathrm{ppm}$ for $\left[\mathrm{TaF}_{6}\right]^{-} .{ }^{5,6}$ The ${ }^{19} \mathrm{~F}\left\{{ }^{1} \mathrm{H}\right\}$ resonances of the diphosphine containing cations appear as broad lines to low frequency of the resonances for the corresponding anions (complexes with $\mathrm{N}-$, S- or O-donor ligands usually have resonances to high frequency of the corresponding $\left[\mathrm{MF}_{6}\right]^{-}$anion $\left.^{4-7}\right)$. Under higher resolution, binomial quintet couplings are apparent on the cation resonances, which are assigned as ${ }^{2} J_{\mathrm{PF}} \sim 40-60 \mathrm{~Hz}$ (Table 2) due to coupling with the four equivalent phosphorus centres (Fig. 4). In most cases the couplings are clearly resolved, although in $\left[\mathrm{NbF}_{4}\left\{0-\mathrm{C}_{6} \mathrm{H}_{4}\left(\mathrm{PMe}_{2}\right)_{2}\right\}_{2}\right]\left[\mathrm{NbF}_{6}\right]$ and $\left[\mathrm{NbF}_{4}\left\{0-\mathrm{C}_{6} \mathrm{H}_{4}\left(\mathrm{PPh}_{2}\right)_{2}\right\}_{2}\right]\left[\mathrm{NbF}_{6}\right]$ they appear as shoulders on a single broad resonance. Apart from small temperature drifts, the ${ }^{19} \mathrm{~F}\left\{{ }^{1} \mathrm{H}\right\}$ change little on cooling the solutions to $223 \mathrm{~K}$, showing exchange processes are slow even at room temperature. This contrasts with the thioether complexes, ${ }^{6,7}$ which showed only a single very broad resonance at room temperature due to rapid dissociative ligand exchange, and which exhibited separate resonances for cation and anion only at low temperatures. The ${ }^{31} \mathrm{P}\left\{{ }^{1} \mathrm{H}\right\}$ NMR spectra of the diphosphine complexes each show a single resonance, with very large high frequency coordination shifts (Table 2). In some cases under high resolution these resonances show binomial quintet 


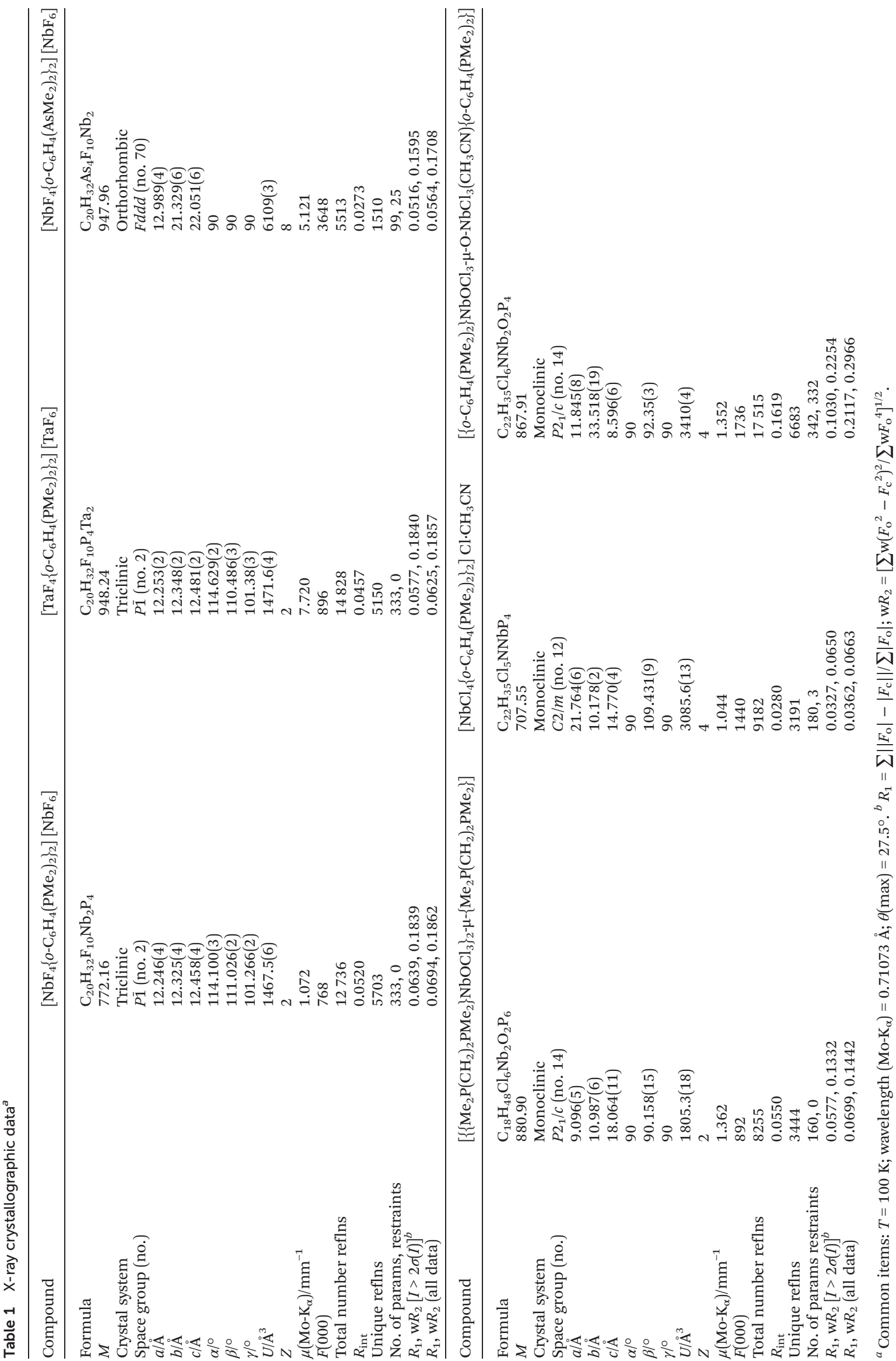




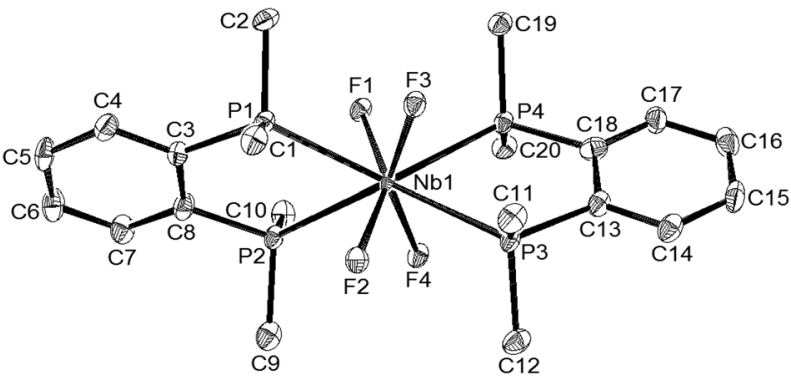

Fig. 1 The cation of $\left[\mathrm{NbF}_{4}\left\{\mathrm{O}-\mathrm{C}_{6} \mathrm{H}_{4}\left(\mathrm{PMe}_{2}\right)_{2}\right\}_{2}\right]\left[\mathrm{NbF}_{6}\right]$, ellipsoids are drawn at the $40 \%$ level. Selected bond lengths $(\AA)$ and angles $\left({ }^{\circ}\right)$ : Nb1-F3 = 1.952(4), Nb1-F2 = 1.952(5), Nb1-F1 = 1.955(4), Nb1-F4 = 1.960(4), $\mathrm{Nb} 1-\mathrm{P} 1=2.637(2), \mathrm{Nb} 1-\mathrm{P} 4=2.642(2), \mathrm{Nb} 1-\mathrm{P} 2=2.651(2), \mathrm{Nb} 1-\mathrm{P} 3=$ $2.654(2), \mathrm{P} 1-\mathrm{Nb} 1-\mathrm{P} 2=71.35(7), \mathrm{P} 4-\mathrm{Nb} 1-\mathrm{P} 3=71.38(7), \mathrm{F} 3-\mathrm{Nb} 1-\mathrm{F} 2=$ 95.29(19), F3-Nb1-F1 = 92.86(19), F2-Nb1-F4 = 92.78(19), F1-Nb1-F4 $=95.35(19)$.

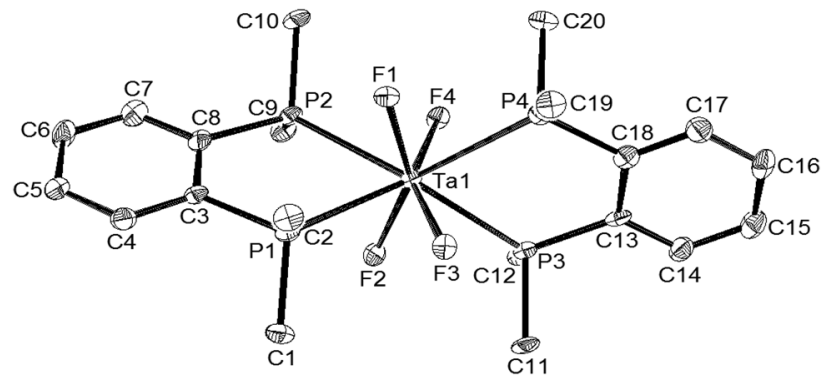

Fig. 2 The cation of $\left.\left[\mathrm{TaF}_{4}\left\{\mathrm{O}-\mathrm{C}_{6} \mathrm{H}_{4}\left(\mathrm{PMe}_{2}\right)_{2}\right\}_{2}\right] \mathrm{TaF}_{6}\right]$, ellipsoids are drawn at the $40 \%$ level. Selected bond lengths (Å) and angles $\left({ }^{\circ}\right)$ : Ta1-F2 = 1.944(9), Ta1-F3 = 1.950(10), Ta1-F1 = 1.955(9), Ta1-F4 = 1.970(9), Ta1$\mathrm{P} 1=2.645(4), \mathrm{Ta} 1-\mathrm{P} 4=2.657(4), \mathrm{Ta} 1-\mathrm{P} 3=2.658(4), \mathrm{Ta} 1-\mathrm{P} 2=2.664(4)$, $\mathrm{P} 1-\mathrm{Ta} 1-\mathrm{P} 2=71.61(13), \mathrm{P} 4-\mathrm{Ta} 1-\mathrm{P} 3=71.53(13), \mathrm{F} 2-\mathrm{Ta} 1-\mathrm{F} 3=95.5(4)$, F3-Ta1-F1 = 93.0(4), F2-Ta1-F4 = 92.9(4), F1-Ta1-F4 = 96.0(4).

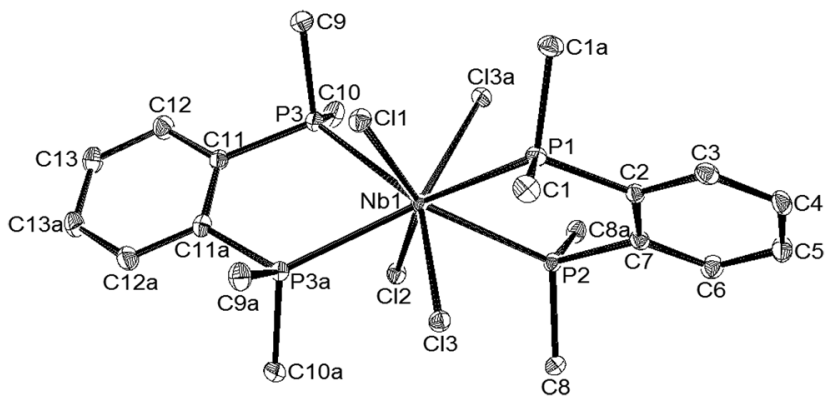

Fig. 3 The cation of $\left[\mathrm{NbCl}_{4}\left\{\mathrm{O}-\mathrm{C}_{6} \mathrm{H}_{4}\left(\mathrm{PMe}_{2}\right)_{2}\right\}_{2}\right] \mathrm{Cl}$, ellipsoids are drawn at the $40 \%$ level. Selected bond lengths $(\AA)$ and angles $\left({ }^{\circ}\right)$ : Nb1-Cl1 = $2.4309(9), \mathrm{Nb} 1-\mathrm{Cl} 3=2.4341(6), \mathrm{Nb} 1-\mathrm{Cl} 2=2.4424(10), \mathrm{Nb} 1-\mathrm{P} 3=$ $2.6833(7), \mathrm{Nb} 1-\mathrm{P} 1=2.6843(10), \mathrm{Nb} 1-\mathrm{P} 2=2.6869(10), \mathrm{P} 3-\mathrm{Nb} 1-\mathrm{P} 3 \mathrm{a}=$ $72.32(3), \mathrm{P} 1-\mathrm{Nb} 1-\mathrm{P} 2=73.189(3), \mathrm{Cl} 1-\mathrm{Nb} 1-\mathrm{Cl} 3=94.99(2), \mathrm{Cl} 3-\mathrm{Nb} 1-$ $\mathrm{Cl} 2=95.029(14)$. Symmetry operator $\mathrm{a}=(x,-y, z)$.

patterns due to ${ }^{2} J_{\mathrm{PF}}$, although these were poorly resolved in the spectra of several of the niobium cations.

The ${ }^{93} \mathrm{Nb}$ NMR spectra $\left({ }^{93} \mathrm{Nb}\right.$ : $100 \%$ abundance, $I=9 / 2, \Xi=$ $\left.24.44 \mathrm{MHz}, Q=-0.2 \times 10^{-28} \mathrm{~m}^{2}, D_{\mathrm{c}}=2740\right)$ of $\left[\mathrm{NbF}_{4}(\mathrm{~L}-\mathrm{L})_{2}\right]-$ $\left[\mathrm{NbF}_{6}\right]$, show the characteristic binomial septet at $\delta \sim-1550 \mathrm{ppm}$

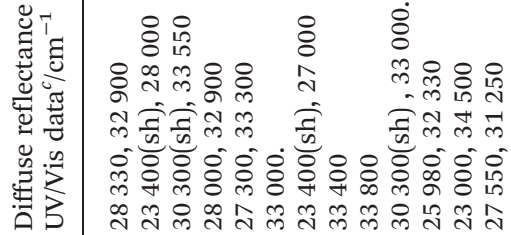

西

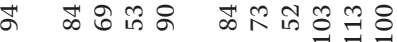

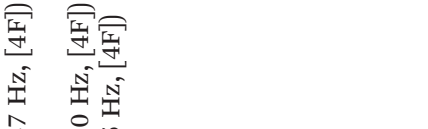

f

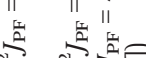

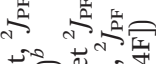

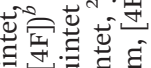

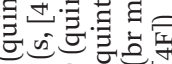

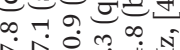

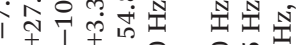

舟- 8 in

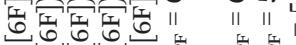

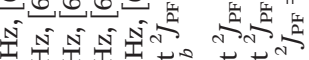

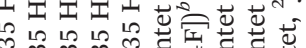

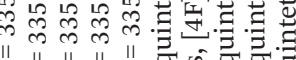

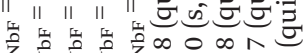

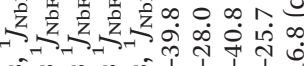

है \&ै \&ै \&

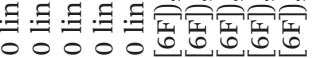

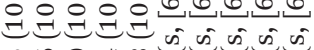

mo 0 . $+\infty$ l

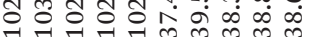

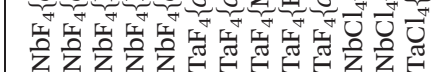

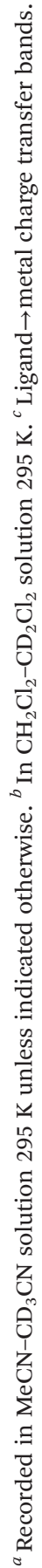



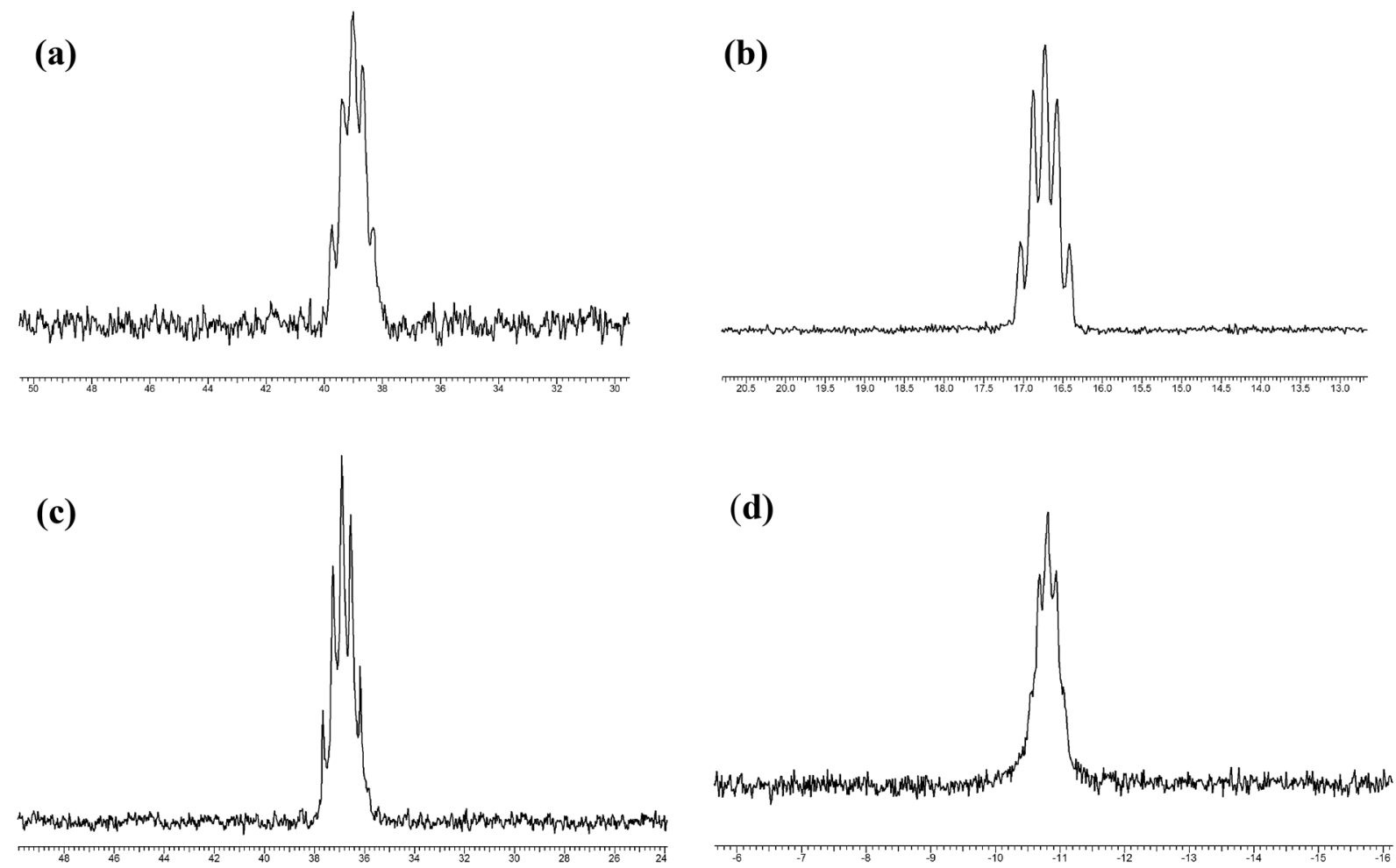

Fig. 4 NMR spectra of the cations: (a) ${ }^{31} \mathrm{P}\left\{{ }^{1} \mathrm{H}\right\}$ of $\left[\mathrm{TaF}_{4}\left\{0-\mathrm{C}_{6} \mathrm{H}_{4}\left(\mathrm{PMe}_{2}\right)_{2}\right\}_{2}\right]^{+}$; (b) ${ }^{19} \mathrm{~F}\left\{{ }^{1} \mathrm{H}\right\}$ of $\left[\mathrm{TaF}_{4}\left\{\mathrm{O}-\mathrm{C}_{6} \mathrm{H}_{4}\left(\mathrm{PMe}_{2}\right)_{2}\right\}_{2}\right]^{+} ;(\mathrm{c}){ }^{31} \mathrm{P}\left\{{ }^{1} \mathrm{H}\right\}$ of $\left[\mathrm{NbF}_{4}\left\{\mathrm{Me}_{2} \mathrm{P}-\right.\right.$ $\left.\left.\left(\mathrm{CH}_{2}\right)_{2} \mathrm{PMe}_{2}\right\}_{2}\right]^{+} ;$(d) $\left.{ }^{19} \mathrm{~F}^{1}{ }^{1} \mathrm{H}\right\}$ of $\left[\mathrm{NbF}_{4}\left\{\mathrm{Me}_{2} \mathrm{P}\left(\mathrm{CH}_{2}\right)_{2} \mathrm{PMe}_{2}\right\}_{2}\right]^{+}$.

for the anion, ${ }^{5}$ but for $\mathrm{L}-\mathrm{L}=o-\mathrm{C}_{6} \mathrm{H}_{4}\left(\mathrm{PMe}_{2}\right)_{2}$ or $\mathrm{Me}_{2} \mathrm{P}$ $\left(\mathrm{CH}_{2}\right)_{2} \mathrm{PMe}_{2}$, very broad features at $\delta \sim-1100 \mathrm{ppm}\left(W_{1 / 2} \sim 5000\right.$ $\mathrm{Hz}$ ) were observed in the room temperature spectra, which are tentatively assigned to the dodecahedral cations; these resonances were lost on cooling the solutions. The complexes are very easily hydrolysed in solution, and trace water results first in the loss of the coupling patterns on the cation resonances, and then complete loss of the cation resonance, although the resonances of the water stable $\left[\mathrm{MF}_{6}\right]^{-}$remain. The diffuse reflectance UV/Vis spectra of the $\left[\mathrm{MF}_{4}\left(\mathrm{diphosphine}_{2}\right]\left[\mathrm{MF}_{6}\right]\right.$ show several broad features in the range $27000-33000 \mathrm{~cm}^{-1}$, which for these $d^{0}$ complexes can be assigned as $P(\sigma) \rightarrow M(d)$ charge transfer transitions since the $\mathrm{F}(\pi) \rightarrow \mathrm{M}(\mathrm{d})$ charge transfer bands are expected to occur in the far-UV. ${ }^{12}$ For those phosphines containing aromatic groups, there are also $\pi \rightarrow \pi^{*}$ transitions in the near-UV region. Comparisons with the corresponding $\left[\mathrm{MCl}_{4}(\text { diphosphine })_{2}\right]\left[\mathrm{MCl}_{6}\right]$ (Table 2) show that the $\mathrm{P}(\sigma) \rightarrow \mathrm{M}(\mathrm{d})$ charge transfer bands occur at higher energy in the fluorides, an effect observed in other systems, ${ }^{7,10}$ and expected due to the strong $\mathrm{M}-\mathrm{F}$ bonding which raises the energy of the metal d-orbitals. The $\mathrm{Cl}(\pi) \rightarrow \mathrm{M}(\mathrm{d})$ charge transfer bands are observed in the near ultraviolet region. ${ }^{13}$ From the data reported (Experimental section) it seems the $\mathrm{Cl}(\pi) \rightarrow \mathrm{M}(\mathrm{d})$ transitions in the dodecahedral cations occur at rather lower energy than in the octahedral anions.

$\ddagger$ In $D_{2 \mathrm{~d}}$ symmetry the metal d-orbitals split $a_{1}+b_{1}+b_{2}+e$, but a more detailed assignment is not possible on the limited data available.

\section{$\left[\mathrm{MF}_{4}\left\{\boldsymbol{o}-\mathrm{C}_{6} \mathrm{H}_{4}\left(\mathrm{AsMe}_{2}\right)_{2}\right\}_{2}\right]\left[\mathrm{MF}_{6}\right]$}

The reaction of $o-\mathrm{C}_{6} \mathrm{H}_{4}\left(\mathrm{AsMe}_{2}\right)_{2}$ with both $\mathrm{MF}_{5}$ reagents in anhydrous MeCN produced $\left[\mathrm{MF}_{4}\left\{o-\mathrm{C}_{6} \mathrm{H}_{4}\left(\mathrm{AsMe}_{2}\right)_{2}\right\}_{2}\right]\left[\mathrm{MF}_{6}\right]$ as cream powders. These are very rare examples of diarsine complexes with high valent fluorides. ${ }^{3} \mathrm{TiF}_{4}$ does not complex with $o$ - $\mathrm{C}_{6} \mathrm{H}_{4}\left(\mathrm{AsMe}_{2}\right)_{2},{ }^{10}$ and the complexes with $\mathrm{SnF}_{4}$ or $\mathrm{GeF}_{4}$ were too unstable to isolate. ${ }^{14,15}$ In contrast to the stability of the diphosphine complexes, the diarsines in $\left[\mathrm{MF}_{4}\{0\right.$ $\left.\left.\mathrm{C}_{6} \mathrm{H}_{4}\left(\mathrm{AsMe}_{2}\right)_{2}\right\}_{2}\right]\left[\mathrm{MF}_{6}\right]$ are partially displaced on dissolution of the complexes in MeCN (NMR evidence), but they are stable for some hours in anhydrous $\mathrm{CH}_{2} \mathrm{Cl}_{2}$ solution, although slow reaction with the solvent occurs over several days. The successful isolation of the diarsine complexes from MeCN results from their deposition as the least soluble species from an exchanging mixture of complex, diarsine and nitrile adducts of $\mathrm{MF}_{5}$ in solution, whilst their relative stability to $\mathrm{CH}_{2} \mathrm{Cl}_{2}$, which contrasts with that of the phosphines, is due to the lower nucleophilicity of the arsenic centres. The $\left[\mathrm{NbF}_{4}\{o-\right.$ $\left.\left.\mathrm{C}_{6} \mathrm{H}_{4}\left(\mathrm{AsMe}_{2}\right)_{2}\right\}_{2}\right]\left[\mathrm{NbF}_{6}\right]$ is not isomorphous with the diphosphine analogue, but shows a similar eight-coordinate cation and six-coordinate anion geometry (Fig. 5).

The $d(\mathrm{Nb}-\mathrm{F})$ in the diarsine complex is slightly longer than those in the diphosphine analogue by $\sim 0.04 \AA$. The complexes of this diarsine with $\mathrm{NbCl}_{5}$ and $\mathrm{TaCl}_{5}$ of type $\left[\mathrm{MCl}_{4}\{o-\right.$ $\left.\left.\mathrm{C}_{6} \mathrm{H}_{4}\left(\mathrm{AsMe}_{2}\right)_{2}\right\}_{2}\right]\left[\mathrm{MCl}_{6}\right]$ \&, were reported many years ago, ${ }^{16}$ and

$\S$ Originally formulated as seven-coordinate monomers. 


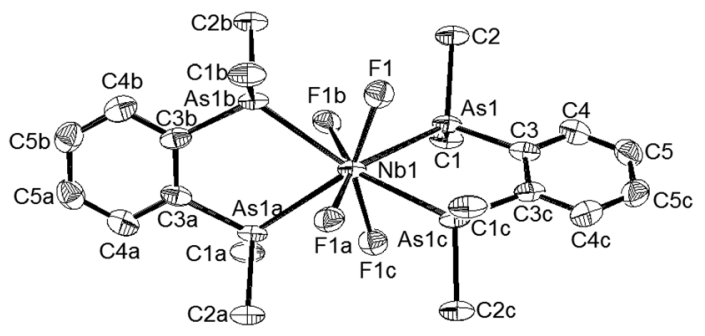

Fig. 5 View of the cation of $\left[\mathrm{NbF}_{4}\left\{\mathrm{O}-\mathrm{C}_{6} \mathrm{H}_{4}\left(\mathrm{AsMe}_{2}\right)_{2}\right\}_{2}\right]\left[\mathrm{NbF}_{6}\right]$. Ellipsoids are drawn at the $40 \%$ level. Selected bond lengths $(\AA)$ and angles $\left(^{\circ}\right)$ : $\mathrm{Nb1}-\mathrm{F} 1=1.991(4), \mathrm{Nb1}-\mathrm{As} 1=2.7518(8), \mathrm{As} 1-\mathrm{Nb1}-\mathrm{As} 1 \mathrm{c}=71.17(3), \mathrm{F} 1-$ $\mathrm{Nb} 1-\mathrm{F} 1 \mathrm{a}=95.6(2), \mathrm{F} 1-\mathrm{Nb} 1-\mathrm{F} 1 \mathrm{c} 148.3(2), \mathrm{F} 1-\mathrm{Nb} 1-\mathrm{F} 1 \mathrm{~b}=92.9(2) . \mathrm{Nb} 1$ lies at the intersection of 3 orthogonal 2 -fold rotation axes. Symmetry operators $a=(x, 5 / 4-y, 1 / 4-z), b=(1 / 4-x, y, 1 / 4-z), c=(1 / 4-x$, $5 / 4-y, z)$.

the X-ray structures are available for $\left[\mathrm{TaCl}_{4}\left\{o-\mathrm{C}_{6} \mathrm{H}_{4}\left(\mathrm{AsMe}_{2}\right)_{2}\right\}_{2}\right]$ $\left[\mathrm{TaCl}_{5}(\mathrm{OEt})\right]^{17}$ and for the $\left[\mathrm{NbCl}_{4}\left\{0-\mathrm{C}_{6} \mathrm{H}_{4}\left(\mathrm{AsMe}_{2}\right)_{2}\right\}_{2}\right]^{+}$with various anions - $\left[\mathrm{NbOCl}_{4}\right]^{-},\left[\mathrm{NbO}_{2} \mathrm{Cl}_{3}\right]^{2-}$ (ref. 17) and $\left[\mathrm{NbCl}_{5}(\mathrm{OEt})\right]^{-}$(see ESI $\dagger$ ). The $d(\mathrm{Nb}-\mathrm{As})$ distances in these various salts are not significantly different to those in $\left[\mathrm{NbF}_{4}\{0\right.$ $\left.\left.\mathrm{C}_{6} \mathrm{H}_{4}\left(\mathrm{AsMe}_{2}\right)_{2}\right\}_{2}\right]\left[\mathrm{NbF}_{6}\right]$. The ${ }^{19} \mathrm{~F}\left\{{ }^{1} \mathrm{H}\right\}$ NMR resonances of the cations in $\left[\mathrm{MF}_{4}\left\{o-\mathrm{C}_{6} \mathrm{H}_{4}\left(\mathrm{AsMe}_{2}\right)_{2}\right\}_{2}\right]\left[\mathrm{MF}_{6}\right]$ are broad singlets to high frequency of the diphosphine analogues (Table 2). In the $\mathrm{UV} / \mathrm{Vis}$ spectrum the $\mathrm{As}(\sigma) \rightarrow \mathrm{M}(\mathrm{d})$ in $\left[\mathrm{MF}_{4}(\text { diarsine })_{2}\right]\left[\mathrm{MF}_{6}\right]$ occur at lower energy $\left(\sim 23000-28000 \mathrm{~cm}^{-1}\right)$ than for the corresponding transitions in the diphosphines, as expected given the lower electronegativity of As. ${ }^{18}$

\section{$\mathrm{NbOF}_{3}$ and $\mathrm{NbOCl}_{3}$ complexes}

We recently reported that reaction of $\mathrm{NbF}_{5}$ with a range of $N$-(2,2'-bipy, 1,10-phen, tmeda) or O-donor $\left(\mathrm{R}_{3} \mathrm{PO}, \mathrm{Ph}_{2} \mathrm{P}(\mathrm{O}) \mathrm{CH}_{2} \mathrm{P}\right.$ (O) $\mathrm{PPh}_{2}$, dmso) ligands in $\mathrm{MeCN}-\mathrm{CH}_{2} \mathrm{Cl}_{2}$ solution, followed by addition of the siloxane, $\mathrm{HMDSO}$, produced white $\left[\mathrm{NbOF}_{3} \mathrm{~L}_{2}\right]$ $\left(\mathrm{L}=\mathrm{R}_{3} \mathrm{PO}, \mathrm{dmso}\right)$ or $\left[\mathrm{NbOF}_{3}\left(\mathrm{~L}^{\prime}-\mathrm{L}^{\prime}\right)\right]\left(\mathrm{L}^{\prime}-\mathrm{L}^{\prime}=2,2^{\prime}\right.$-bipy, 1,10 phen, tmeda or $\left.\mathrm{Ph}_{2} \mathrm{P}(\mathrm{O}) \mathrm{CH}_{2} \mathrm{P}(\mathrm{O}) \mathrm{PPh}_{2}\right)$, although weaker donor ether, nitrile or thioether complexes did not form. ${ }^{5}$ In the present work attempts to use the same approach failed to yield $\mathrm{NbOF}_{3}$-diphosphine adducts, with $\left[\mathrm{NbF}_{4}(\mathrm{~L}-\mathrm{L})_{2}\right]\left[\mathrm{NbF}_{6}\right](\mathrm{L}-\mathrm{L}=$ $\mathrm{Me}_{2} \mathrm{P}\left(\mathrm{CH}_{2}\right)_{2} \mathrm{PMe}_{2}$ or $\left.o-\mathrm{C}_{6} \mathrm{H}_{4}\left(\mathrm{PMe}_{2}\right)_{2}\right)$ solutions in MeCN being unchanged after $24 \mathrm{~h}$. from addition of HMDSO, as shown by ${ }^{19} \mathrm{~F}$ and ${ }^{31} \mathrm{P}$ NMR spectroscopy. Similarly, MeCN solutions of $\left[\mathrm{NbOF}_{3} \mathrm{~L}_{2}\right]\left(\mathrm{L}=\mathrm{dmso}\right.$ or $\left.\mathrm{Ph}_{3} \mathrm{PO}\right)$ did not react with $o-\mathrm{C}_{6} \mathrm{H}_{4}\left(\mathrm{PMe}_{2}\right)_{2}$ or $\mathrm{Me}_{2} \mathrm{P}\left(\mathrm{CH}_{2}\right)_{2} \mathrm{PMe}_{2}$. We have reported elsewhere ${ }^{19}$ that alkyl diphosphines fail to displace the hard O-donor from $\left[\mathrm{ZrF}_{4} \mathrm{~L}_{2}\right](\mathrm{L}=\mathrm{dmso}$ or $\mathrm{dmf})$, and it is plausible that in the $\mathrm{NbOF}_{3}$ systems, the hard $\mathrm{Nb}$ centre prefers the O-donor to the softer phosphorus. However, the failure of the siloxane to perform $\mathrm{O} / \mathrm{F}$ exchange was unexpected and the reason for this is not clear.

Tertiary phosphine complexes of $\mathrm{NbOCl}_{3}$ include both sixcoordinate $\left[\mathrm{NbOCl}_{3}\left(\mathrm{PR}_{3}\right)_{2}\right]\left(\mathrm{R}=\mathrm{Me}, \mathrm{Ph} ; \mathrm{R}_{3}=\mathrm{MePh}_{2}\right)$ and seven-coordinate $\left[\mathrm{NbOCl}_{3}\left(\mathrm{PMe}_{3}\right)_{3}\right]^{20,21}$ In the present work, reaction of $\mathrm{NbCl}_{5}$ with $\mathrm{HMDSO}$ in $\mathrm{MeCN}$, which forms $\left[\mathrm{NbOCl}_{3}(\mathrm{MeCN})_{2}\right]$ in situ, followed by addition of one mol. equivalent of $\mathrm{Me}_{2} \mathrm{P}\left(\mathrm{CH}_{2}\right)_{2} \mathrm{PMe}_{2}$, afforded white $\left[\left(\mathrm{NbOCl}_{3}\right)_{2^{-}}\right.$

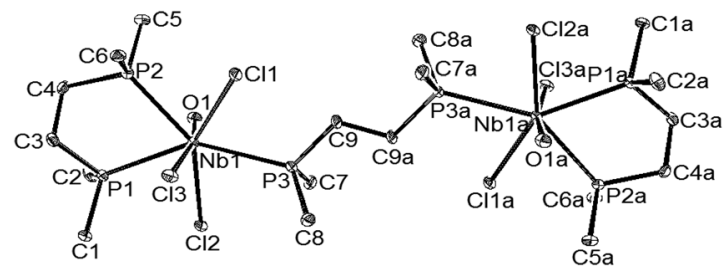

Fig. 6 View of the dimer $\left[\left\{\left\{\mathrm{Me}_{2} \mathrm{P}\left(\mathrm{CH}_{2}\right)_{2} \mathrm{PMe}_{2}\right\} \mathrm{NbOCl}_{3}\right\}_{2}\left\{\mu-\mathrm{Me}_{2} \mathrm{P}-\right.\right.$ $\left.\left(\mathrm{CH}_{2}\right)_{2} \mathrm{PMe}_{2}\right\}$ ]. Ellipsoids are drawn at the $40 \%$ probability level. Selected bond lengths $(\AA)$ and angles $\left({ }^{\circ}\right)$ : Nb1-O1 $=1.724(4), \mathrm{Nb} 1-\mathrm{Cl} 1=2.506(2)$, $\mathrm{Nb} 1-\mathrm{Cl} 2=2.517(2), \mathrm{Nb} 1-\mathrm{Cl} 3=2.605(2), \mathrm{Nb} 1-\mathrm{P} 1=2.6716(19), \mathrm{Nb} 1-\mathrm{P} 2$ $=2.677(2), \mathrm{Nb} 1-\mathrm{P} 3=2.760(2), \mathrm{O} 1-\mathrm{Nb} 1-\mathrm{Cl} 1=97.14(15), \mathrm{O} 1-\mathrm{Nb} 1-\mathrm{Cl} 2=$ 94.74(15), Cl1-Nb1-Cl2 = 145.83(6), O1-Nb1-Cl3 = 167.75(15), Cl1$\mathrm{Nb} 1-\mathrm{Cl} 3=86.36(6), \mathrm{Cl}-\mathrm{Nb} 1-\mathrm{Cl} 3=88.74(6), \mathrm{O} 1-\mathrm{Nb} 1-\mathrm{P} 1=91.43(15)$, $\mathrm{O} 1-\mathrm{Nb} 1-\mathrm{P} 2=85.03(15), \mathrm{O} 1-\mathrm{Nb} 1-\mathrm{P} 3=94.84(15), \mathrm{P} 1-\mathrm{Nb} 1-\mathrm{P} 2=$ 71.04(6). Symmetry operator $a=(-x,-y,-z)$.

$\left.\left\{\mathrm{Me}_{2} \mathrm{P}\left(\mathrm{CH}_{2}\right)_{2} \mathrm{PMe}_{2}\right\}_{3}\right]$. The structure determined from colourless crystals grown from $\mathrm{CH}_{2} \mathrm{Cl}_{2}$ solution, showed this to be the symmetric dimer $\left[\left\{\left\{\mathrm{Me}_{2} \mathrm{P}\left(\mathrm{CH}_{2}\right)_{2} \mathrm{PMe}_{2}\right\} \mathrm{NbOCl}_{3}\right\}_{2}\left\{\mu-\mathrm{Me}_{2} \mathrm{P}-\right.\right.$ $\left.\left(\mathrm{CH}_{2}\right)_{2} \mathrm{PMe}_{2}\right\}$ ] (Fig. 6), containing seven-coordinate niobium.

The bond lengths are similar to those in $\left[\mathrm{NbOCl}_{3}\left(\mathrm{PMe}_{3}\right)_{3}\right]^{20}$ but the geometry is quite different, due to the presence of the five-membered chelate ring, with $\mathrm{P} 1-\mathrm{Nb} 1-\mathrm{P} 2=71.04(6)^{\circ}$, whereas in $\left[\mathrm{NbOCl}_{3}\left(\mathrm{PMe}_{3}\right)_{3}\right]$ the $\mathrm{P}-\mathrm{Nb}-\mathrm{P}$ angles are all $>112^{\circ}$. The $\nu(\mathrm{Nb}=\mathrm{O})$ of $939 \mathrm{~cm}^{-1}$ in $\left[\left\{\left\{\mathrm{Me}_{2} \mathrm{P}\left(\mathrm{CH}_{2}\right)_{2} \mathrm{PMe}_{2}\right\} \mathrm{NbOCl}_{3}\right\}_{2^{-}}\right.$ $\left.\left\{\mu-\mathrm{Me}_{2} \mathrm{P}\left(\mathrm{CH}_{2}\right)_{2} \mathrm{PMe}_{2}\right\}\right]$ contrasts with that of $882 \mathrm{~cm}^{-1}$ reported for $\left[\mathrm{NbOCl}_{3}\left(\mathrm{PMe}_{3}\right)_{3}\right]^{20,21}$ The dimer structure is retained in solution, shown most clearly by the ${ }^{1} \mathrm{H}$ and ${ }^{31} \mathrm{P}\left\{{ }^{1} \mathrm{H}\right\}$ NMR spectra, which distinguish the bridging and chelating diphosphines. The phosphorus resonance $[2 \mathrm{P}]$ of the bridging ligand has a coordination shift $(\Delta)$ of +47 , whereas the more intense resonance $[4 \mathrm{P}]$ has $\Delta=+80$, indicative of a five-membered chelate ring. ${ }^{22}$

The reaction of $\mathrm{NbCl}_{5}$ and HMDSO in MeCN followed by addition of $o-\mathrm{C}_{6} \mathrm{H}_{4}\left(\mathrm{PMe}_{2}\right)_{2}$, gave a white precipitate identified as $\left[\left\{o-\mathrm{C}_{6} \mathrm{H}_{4}\left(\mathrm{PMe}_{2}\right)_{2}\right\} \mathrm{NbOCl}_{3}(\mu-\mathrm{O}) \mathrm{NbCl}_{3}\left(\mathrm{CH}_{3} \mathrm{CN}\right)\left\{o-\mathrm{C}_{6} \mathrm{H}_{4}\left(\mathrm{PMe}_{2}\right)_{2}\right\}\right]$, and red-orange $\left[\mathrm{NbCl}_{4}\left\{o-\mathrm{C}_{6} \mathrm{H}_{4}\left(\mathrm{PMe}_{2}\right)_{2}\right\}_{2}\right]\left[\mathrm{NbOCl}_{4}\left(\mathrm{CH}_{3} \mathrm{CN}\right)\right]$ was isolated from the filtrate. The structure of the latter is described in ESI. $\dagger$

The former contains seven-coordinate niobium centres, but in contrast to $\left[\left(\mathrm{NbOCl}_{3}\right)_{2}\left\{\mathrm{Me}_{2} \mathrm{P}\left(\mathrm{CH}_{2}\right)_{2} \mathrm{PMe}_{2}\right\}_{3}\right]$, the two niobium centres have different ligand donor sets $\left(\mathrm{P}_{2} \mathrm{O}_{2} \mathrm{Cl}_{3}\right.$ and $\left.\mathrm{P}_{2} \mathrm{NOCl}_{3}\right)$ and are linked by a near-linear $\left(177^{\circ}\right)$ oxido-bridge (Fig. 7). It may be that the rigid $o-\mathrm{C}_{6} \mathrm{H}_{4}\left(\mathrm{PMe}_{2}\right)_{2}$, which is pre-organised for chelation, is disfavoured as a bridge in this case and the oxido-bridge is formed instead. The CSD contains only a single example of $o-\mathrm{C}_{6} \mathrm{H}_{4}\left(\mathrm{PMe}_{2}\right)_{2}$ coordinated as a bridging ligand, in $\left[\left(\mathrm{Cp}^{*} \mathrm{IrC1}_{2}\right)_{2}\left\{\mu-o-\mathrm{C}_{6} \mathrm{H}_{4}\left(\mathrm{PMe}_{2}\right)_{2}\right\}\right] .{ }^{23}$

\section{Conclusions}

A new series of complexes of niobium(v) and tantalum(v) fluoride with soft, neutral phosphorus or arsenic donor ligands has been prepared and characterised. All are of type $\left[\mathrm{MF}_{4}(\mathrm{~L}-\mathrm{L})_{2}\right]-$ $\left[\mathrm{MF}_{6}\right]$ containing eight-coordinate cations, which seem to be 


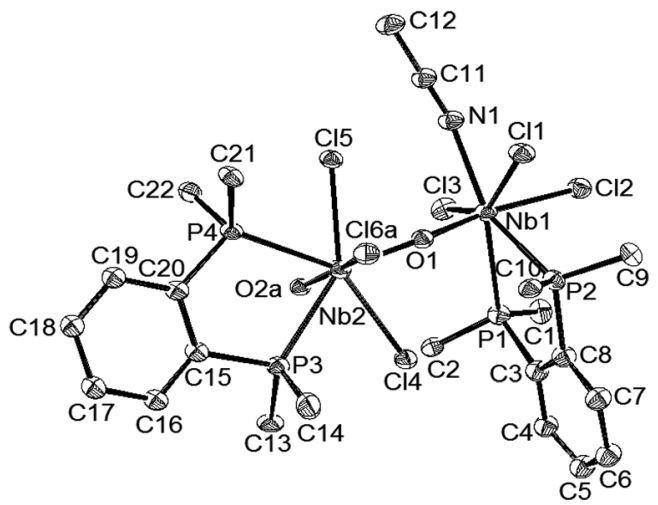

Fig. 7 The structure of $\left[\left\{0-\mathrm{C}_{6} \mathrm{H}_{4}\left(\mathrm{PMe}_{2}\right)_{2}\right\} \mathrm{NbOCl}_{3}(\mu-\mathrm{O}) \mathrm{NbCl}_{3}\left(\mathrm{CH}_{3} \mathrm{CN}\right)\{\mathrm{O}-\right.$ $\left.\left.\mathrm{C}_{6} \mathrm{H}_{4}\left(\mathrm{PMe}_{2}\right)_{2}\right\}\right]$, with ellipsoids drawn at the $40 \%$ probability level. There is disorder around $\mathrm{Nb2}$, involving $\mathrm{O} 2 \mathrm{a}$ and $\mathrm{Cl} 6 \mathrm{a}$, and only the major component is shown. Selected bond lengths $(\AA)$ and angles $\left({ }^{\circ}\right)$ : $\mathrm{Cl} 1-\mathrm{Nb} 1$ $=2.451(4), \mathrm{Cl} 2-\mathrm{Nb} 1=2.507(4), \mathrm{Cl} 3-\mathrm{Nb} 1=2.497(4), \mathrm{Cl} 4-\mathrm{Nb} 2=$ 2.489(4), $\mathrm{Cl} 5-\mathrm{Nb} 2=2.478(4), \mathrm{N} 1-\mathrm{Nb} 1=2.268(13), \mathrm{Nb} 1-\mathrm{O} 1=1.757(10)$, $\mathrm{Nb} 1-\mathrm{P} 2=2.658(4), \mathrm{Nb} 1-\mathrm{P} 1=2.668(5), \mathrm{Nb} 2-\mathrm{O} 2 \mathrm{~A}=1.843(13), \mathrm{Nb} 2-\mathrm{O} 1$ $=2.197(10), \mathrm{Nb} 2-\mathrm{Cl} 6 \mathrm{~A}=2.479(5), \mathrm{Nb} 2-\mathrm{P} 4=2.652(5), \mathrm{Nb} 2-\mathrm{P} 3=$ 2.671(4), Nb1-O1-Nb2 = 177.5(6), P2-Nb1-P1 = 71.43(13), P4-Nb2-P3 $=71.92(13)$.

the preferred structural units for many complexes of these two $\mathrm{M}(\mathrm{v})$ fluorides. ${ }^{3}$ Despite the extreme hard/soft Lewis acid/base combinations, they are robust complexes with no evidence for decomposition in the solid state if protected from moisture, and the NMR spectra show no significant dissociation of the ligands in inert solvents at ambient temperatures. These properties contrast with those of complexes containing other soft donors, e.g. the rapid decomposition of the selenoether complexes with fluorination at selenium, and the extensive dissociation of the thioether adducts in solution at ambient temperatures. ${ }^{6,7}$ The properties also contrast with the very unstable phosphine complexes of $\mathrm{TiF}_{4}$, and the absence of any arsine ligand adducts with $\mathrm{TiF}_{4}, \mathrm{GeF}_{4}$ or $\mathrm{SnF}_{4} \cdot{ }^{10,14,15}$ Comparisons with the corresponding complexes of $\mathrm{Nb}$ or $\mathrm{Ta}$ pentachlorides show considerable similarities, both in composition and properties, which contrasts with the behaviour of Group 4 tetrahalides, where there is little in common between the chemistries of $\mathrm{ZrF}_{4}$ or $\mathrm{HfF}_{4}$ (which do not form complexes with soft donor ligands), ${ }^{19}$ and the six- or eightcoordinate complexes formed the heavier tetrahalides. ${ }^{24}$ The coordination chemistry of $\mathrm{TiF}_{4}$ is also very different from those of $\operatorname{TiX}_{4}\left(\mathrm{X}=\mathrm{Cl}, \mathrm{Br}\right.$ or I) ${ }^{10,25}$ The coordination chemistry of $\mathrm{VF}_{4}$ merits thorough study, and on the basis of the results reported herein, it is possible that even $\mathrm{VF}_{5}$ may form neutral ligand complexes under appropriate conditions. ${ }^{3}$

\section{Experimental}

Infrared spectra were recorded as Nujol mulls between CsI plates using a Perkin Elmer Spectrum 100 over the range $4000-200 \mathrm{~cm}^{-1}$. ${ }^{1} \mathrm{H}$ NMR spectra were recorded from $\mathrm{CD}_{2} \mathrm{Cl}_{2}$ or $\mathrm{CD}_{3} \mathrm{CN}$ solutions using a Bruker DPX400 spectrometer.
${ }^{19} \mathrm{~F}\left\{{ }^{1} \mathrm{H}\right\},{ }^{31} \mathrm{P}\left\{{ }^{1} \mathrm{H}\right\}$ and ${ }^{93} \mathrm{Nb}$ NMR spectra were recorded using a Bruker DPX400 spectrometer and are referenced to external $\mathrm{CFCl}_{3}$, external $85 \% \mathrm{H}_{3} \mathrm{PO}_{4}$, and $\left[\mathrm{Et}_{4} \mathrm{~N}\right]\left[\mathrm{NbCl}_{6}\right]$ in $\mathrm{MeCN}$ respectively. UV/visible spectra were recorded from solid samples diluted with $\mathrm{BaSO}_{4}$ using the diffuse reflectance attachment of a Perkin-Elmer Lambda 19 spectrometer. Microanalyses on new complexes were undertaken by London Metropolitan University. Preparations used standard Schlenk and glove box techniques under a $\mathrm{N}_{2}$ atmosphere with rigorous exclusion of moisture. Solvents were dried by distillation from $\mathrm{CaH}_{2}\left(\mathrm{CH}_{2} \mathrm{Cl}_{2}\right.$ or $\left.\mathrm{CH}_{3} \mathrm{CN}\right)$ or $\mathrm{Na}$ /benzophenone ketyl (diethyl ether). Hexamethyldisiloxane was dried over molecular sieves. Anhydrous $\mathrm{NbX}_{5}$ and $\mathrm{TaX}_{5}(\mathrm{X}=\mathrm{F}$ or $\mathrm{Cl}), \mathrm{PMe}_{3}, \mathrm{Me}_{2} \mathrm{P}-$ $\left(\mathrm{CH}_{2}\right)_{2} \mathrm{PMe}_{2}, \mathrm{Et}_{2} \mathrm{P}\left(\mathrm{CH}_{2}\right)_{2} \mathrm{PEt}_{2}$ and $o-\mathrm{C}_{6} \mathrm{H}_{4}\left(\mathrm{PPh}_{2}\right)_{2}$ were obtained from Aldrich, Apollo or Strem and used as received. $o$ - $\mathrm{C}_{6} \mathrm{H}_{4}\left(\mathrm{PMe}_{2}\right)_{2}$ and $o-\mathrm{C}_{6} \mathrm{H}_{4}\left(\mathrm{AsMe}_{2}\right)_{2}$ were made by literature methods. ${ }^{26,27}$

$\left[\mathbf{N b F}_{4}\left\{\boldsymbol{o}-\mathbf{C}_{6} \mathbf{H}_{4}\left(\mathbf{P M e}_{2}\right)_{2}\right\}_{2}\right]\left[\mathbf{N b F}_{6}\right]: \mathrm{NbF}_{5}(0.18 \mathrm{~g}, 1.0 \mathrm{mmol})$ was dissolved in anhydrous MeCN $(10 \mathrm{~mL})$ and $o-\mathrm{C}_{6} \mathrm{H}_{4}\left(\mathrm{PMe}_{2}\right)_{2}$ $(0.20 \mathrm{~g}, 1.0 \mathrm{mmol})$ added. A clear solution formed which deposited a cream precipitate after $\sim 20 \mathrm{~min}$. After stirring for $1 \mathrm{~h}$ the precipitate was filtered off, rinsed with $\mathrm{MeCN}(2 \mathrm{~mL})$ and dried in vacuo. White powder. Yield: $0.30 \mathrm{~g}, 79 \%$. Anal: required for $\mathrm{C}_{20} \mathrm{H}_{32} \mathrm{~F}_{10} \mathrm{Nb}_{2} \mathrm{P}_{4}$ (772.2): $\mathrm{C}, 31.1 ; \mathrm{H}, 4.2$. Found: $\mathrm{C}$, $31.0 ; \mathrm{H}, 4.0 \% .{ }^{1} \mathrm{H}$ NMR $\left(\mathrm{CD}_{3} \mathrm{CN}, 295 \mathrm{~K}\right): \delta=1.70(\mathrm{br} \mathrm{s},[12 \mathrm{H}])$, $7.82(0[2 \mathrm{H}]), 7.95(\mathrm{~s},[2 \mathrm{H}]) .{ }^{19} \mathrm{~F}\left\{{ }^{1} \mathrm{H}\right\}$ NMR $\left(\mathrm{CD}_{3} \mathrm{CN}, 298 \mathrm{~K}\right): \delta=$ $102.3\left([6 \mathrm{~F}], 10\right.$ lines, $\left.{ }^{1} J_{\mathrm{NbF}}=335 \mathrm{~Hz},\left[\mathrm{NbF}_{6}\right]^{-}\right),-7.8$ (quintet, ${ }^{2} J_{\mathrm{PF}}=47 \mathrm{~Hz},[4 \mathrm{~F}]$, cation); (243 K) $102.3\left([6 \mathrm{~F}], 10\right.$ lines, ${ }^{1} J_{\mathrm{NbF}}=$ $335 \mathrm{~Hz}),-10.8$ (br s, $[4 \mathrm{~F}]) .{ }^{31} \mathrm{P}\left\{{ }^{1} \mathrm{H}\right\}$ NMR $\left(\mathrm{CD}_{3} \mathrm{CN}, 298 \mathrm{~K}\right): \delta=$ 38.9 (br m); (233 K) 39.5 (br m). ${ }^{93} \mathrm{Nb}$ NMR $\left(\mathrm{CD}_{3} \mathrm{CN}, 298 \mathrm{~K}\right): \delta=$ $\sim-1110$ (vbr, cation), -1553 (septet, $\left.\left[\mathrm{NbF}_{6}\right]^{-}\right)$; $(233 \mathrm{~K}):-1554$ (septet). IR (Nujol)/cm ${ }^{-1}$ : 611 (vbr), 588 (sh) (NbF). UV/Vis (dr)/ $\mathrm{cm}^{-1}: 28330,32900$.

$\left[\mathbf{N b F}_{4}\left\{\boldsymbol{o}-\mathbf{C}_{6} \mathbf{H}_{4}\left(\mathbf{A s M e}_{2}\right)_{2}\right\}_{2}\right]\left[\mathbf{N b F}_{6}\right]: \operatorname{NbF}_{5}(0.18 \mathrm{~g}, 1.0 \mathrm{mmol})$ was dissolved in anhydrous MeCN $(15 \mathrm{~mL})$ and $o-\mathrm{C}_{6} \mathrm{H}_{4}\left(\mathrm{AsMe}_{2}\right)_{2}(0.29 \mathrm{~g}, 1.0 \mathrm{mmol})$ added. A clear yellow solution formed which deposited a pale yellow-cream precipitate after $\sim 20 \mathrm{~min}$. After stirring for $1 \mathrm{~h}$ the solution was concentrated to $\sim 5 \mathrm{~mL}$, the precipitate was filtered off, rinsed with MeCN $(2 \mathrm{~mL})$ and dried in vacuo. Yellow powder. Yield: $0.40 \mathrm{~g}, 85 \%$. Anal: required for $\mathrm{C}_{20} \mathrm{H}_{32} \mathrm{As}_{4} \mathrm{~F}_{10} \mathrm{Nb}_{2}$ (948.0): C, 25.3; $\mathrm{H}$, 5.4. Found: C, 25.4; H, 5.3\%. ${ }^{1} \mathrm{H}$ NMR $\left(\mathrm{CD}_{2} \mathrm{Cl}_{2}, 293 \mathrm{~K}\right): \delta=1.63(\mathrm{~s}$, $[12 \mathrm{H}]), 7.58(\mathrm{~s},[2 \mathrm{H}]), 7.67(\mathrm{~s},[2 \mathrm{H}]) ;(243 \mathrm{~K}): 1.63(\mathrm{~s},[12 \mathrm{H}]), 7.56$ (s, [2H]), $7.64(\mathrm{~s},[2 \mathrm{H}]) \cdot{ }^{19} \mathrm{~F}\left\{{ }^{1} \mathrm{H}\right\} \mathrm{NMR}\left(\mathrm{CD}_{2} \mathrm{Cl}_{2}, 293 \mathrm{~K}\right): \delta=103.6$ $\left([6 \mathrm{~F}], 10\right.$ lines $\left.{ }^{1} J_{\mathrm{NbF}}=335 \mathrm{~Hz},\left[\mathrm{NbF}_{6}\right]^{-}\right), 27.1(\mathrm{~s},[4 \mathrm{~F}]$, cation); (233 K): 103.6 (10 lines), 24.6 (s). ${ }^{93} \mathrm{Nb}$ NMR $\left(\mathrm{CD}_{2} \mathrm{Cl}_{2}, 293 \mathrm{~K}\right): \delta$ $=-1549$ (septet, $\left[\mathrm{NbF}_{6}\right]^{-}$). IR (Nujol) $/ \mathrm{cm}^{-1}: 620(\mathrm{sh}), 610(\mathrm{sbr})$, 586 (sh) (NbF). UV/Vis (dr)/ $\mathrm{cm}^{-1}: 23400$ (sh), 28 000, 32050.

$\left[\mathbf{N b F}_{4}\left\{\mathbf{M e}_{2} \mathbf{P}\left(\mathbf{C H}_{2}\right)_{2} \mathbf{P M e}_{2}\right\}_{2}\right]\left[\mathbf{N b F}_{6}\right]: \mathrm{NbF}_{5}(0.18 \mathrm{~g}, 1.0 \mathrm{mmol})$ was dissolved in anhydrous MeCN (15 mL) and $\mathrm{Me}_{2} \mathrm{P}-$ $\left(\mathrm{CH}_{2}\right)_{2} \mathrm{PMe}_{2}(0.15 \mathrm{~g}, 1.0 \mathrm{mmol})$ added. A clear solution formed which deposited a white powder on stirring. After stirring for $1 \mathrm{~h}$ the solution was concentrated to $\sim 5 \mathrm{~mL}$, and dry diethyl ether $(5 \mathrm{~mL})$ added. The precipitate was filtered off, rinsed with MeCN $(2 \mathrm{~mL})$ and dried in vacuo. White powder. Yield: $0.25 \mathrm{~g}, 76 \%$. Anal: required for $\mathrm{C}_{12} \mathrm{H}_{32} \mathrm{~F}_{10} \mathrm{Nb}_{2} \mathrm{P}_{4}$ (676.1): C, 
21.3; H, 4.8. Found: C, 21.1; H, 4.9\%. ${ }^{1} \mathrm{H}$ NMR ( $\left.\mathrm{CD}_{3} \mathrm{CN}, 293 \mathrm{~K}\right)$ : $\delta=1.94(\mathrm{~s},[12 \mathrm{H}]), 2.33(\mathrm{~s},[4 \mathrm{H}]) ;(233 \mathrm{~K}): 1.96(\mathrm{~s},[12 \mathrm{H}]), 2.33$ (s, [4H]). ${ }^{19} \mathrm{~F}\left\{{ }^{1} \mathrm{H}\right\}$ NMR $\left(\mathrm{CD}_{3} \mathrm{CN}, 293 \mathrm{~K}\right): \delta=102.0$ ([6F], 10 lines ${ }^{1} J_{\mathrm{NbF}}=335 \mathrm{~Hz},\left[\mathrm{NbF}_{6}\right]^{-}$), -10.9 (quintet ${ }^{2} J_{\mathrm{PF}}=60 \mathrm{~Hz},[4 \mathrm{~F}]$, cation); (233 K): 102.7 ([6F], 10 lines, $\left.{ }^{1} J_{\mathrm{NbF}}=335 \mathrm{~Hz},\right),-13.8$ (quintet, [4F]). ${ }^{31} \mathrm{P}\left\{{ }^{1} \mathrm{H}\right\} \mathrm{NMR}\left(\mathrm{CD}_{3} \mathrm{CN}, 293 \mathrm{~K}\right): \delta=36.9$ (quintet, $\left.{ }^{2} J_{\mathrm{PF}}=60 \mathrm{~Hz}\right) ;(233 \mathrm{~K}): 38.0$ (quintet). ${ }^{93} \mathrm{Nb} \mathrm{NMR}\left(\mathrm{CD}_{3} \mathrm{CN}\right.$, $293 \mathrm{~K}): \delta=-1062$ (vbr, s, cation), -1553 (septet, $\left[\mathrm{NbF}_{6}\right]^{-}$); (233 K): -1555 (septet). IR (Nujol) $/ \mathrm{cm}^{-1}: 614$ (sh), 573 (sbr), 554 (sh) (NbF). UV/Vis (dr)/cm $\mathrm{cm}^{-1}: 30300$ (sh), 33550.

$\left[\mathbf{N b F}_{\mathbf{4}}\left\{\mathbf{E t}_{\mathbf{2}} \mathbf{P}\left(\mathbf{C H}_{2}\right)_{2} \mathbf{P E t}_{2}\right\}_{2}\right]\left[\mathbf{N b F}_{\mathbf{6}}\right]$ : was made similarly. The complex is more soluble in MeCN and was isolated by removing the MeCN in vacuo and stirring the waxy white residue with dry diethyl ether $(10 \mathrm{~mL})$ for $2 \mathrm{~h}$, after which the powder was filtered off and dried. White powder. Yield: 78\%. Anal: required for $\mathrm{C}_{20} \mathrm{H}_{48} \mathrm{~F}_{10} \mathrm{Nb}_{2} \mathrm{P}_{4}$ (788.3): $\mathrm{C}, 30.5 ; \mathrm{H}, 6.1$. Found: $\mathrm{C}$, 30.4; H, 6.1\%. ${ }^{1} \mathrm{H}$ NMR $\left(\mathrm{CD}_{3} \mathrm{CN}, 293 \mathrm{~K}\right): \delta=1.13$ (br s, $[12 \mathrm{H}]$ ), $1.89(\mathrm{~m},[8 \mathrm{H}]), 2.15(\mathrm{~m},[4 \mathrm{H}]) ;(233 \mathrm{~K}): 1.07(\mathrm{~m},[12 \mathrm{H}]), 1.85(\mathrm{~m}$, $[8 \mathrm{H}]), 2.16(\mathrm{~m},[4 \mathrm{H}]) .{ }^{19} \mathrm{~F}\left\{{ }^{1} \mathrm{H}\right\} \mathrm{NMR}\left(\mathrm{CD}_{3} \mathrm{CN}, 293 \mathrm{~K}\right): \delta=102.4$ $\left([6 \mathrm{~F}], 10\right.$ lines, ${ }^{1} J_{\mathrm{NbF}}=335 \mathrm{~Hz},\left[\mathrm{NbF}_{6}\right]^{-}$), +3.3 (quintet, ${ }^{2} J_{\mathrm{PF}}=$ $45 \mathrm{~Hz},[4 \mathrm{~F}]$, cation); ( $\left.\mathrm{CD}_{3} \mathrm{CN}, 243 \mathrm{~K}\right): 101.9$ (10 lines), +0.04 (quintet, $\left.{ }^{2} J_{\mathrm{PF}}=45 \mathrm{~Hz},[4 \mathrm{~F}]\right) .{ }^{31} \mathrm{P}\left\{{ }^{1} \mathrm{H}\right\} \mathrm{NMR}\left(\mathrm{CD}_{3} \mathrm{CN}, 293 \mathrm{~K}\right): \delta=$ 50.3 (br s); (233 K): 50.0 (br m). ${ }^{93} \mathrm{Nb} \mathrm{NMR}\left(\mathrm{CD}_{3} \mathrm{CN}, 293 \mathrm{~K}\right): \delta=$ -1553 (septet, $\left.\left[\mathrm{NbF}_{6}\right]^{-}\right)$; (233 K): -1555 (septet). IR (Nujol)/ $\mathrm{cm}^{-1}: 630(\mathrm{sh}), 611$ (sbr) (NbF). UV/Vis (dr)/ $\mathrm{cm}^{-1}: 28000$, 32900 .

$\left[\mathbf{N b F}_{4}\left\{\boldsymbol{o}-\mathbf{C}_{\mathbf{6}} \mathbf{H}_{\mathbf{4}}\left(\mathbf{P P h}_{\mathbf{2}}\right)_{2}\right\}_{2}\right]\left[\mathbf{N b F}_{\mathbf{6}}\right]: \quad$ Powdered $o-\mathrm{C}_{6} \mathrm{H}_{4}\left(\mathrm{PPh}_{2}\right)_{2}$ $(0.40 \mathrm{~g}, 0.9 \mathrm{mmol})$ was suspended in dry MeCN $(20 \mathrm{~mL})$ and the mixture stirred vigorously. Powdered $\mathrm{NbF}_{5}(0.16 \mathrm{~g}$, $0.9 \mathrm{mmol}$ ) was added and after $\sim 5$ min a clear solution was produced. After a further $3 \mathrm{~h}$ the solution was concentrated to $\sim 5 \mathrm{~mL}$ in vacuo, when a pale cream solid deposited. This was filtered off, rinsed with MeCN (1 mL) and dried in vacuo. Yield: $0.39 \mathrm{~g}, 70 \%$. Anal: required for $\mathrm{C}_{60} \mathrm{H}_{48} \mathrm{~F}_{10} \mathrm{Nb}_{2} \mathrm{P}_{4}$ (1268.7): C, 56.8; H, 3.8. Found: C, 56.9; H, 3.6\%. ${ }^{1} \mathrm{H}$ NMR $\left(\mathrm{CD}_{2} \mathrm{Cl}_{2} 293 \mathrm{~K}\right)$ : $\delta=7.65-7.23(\mathrm{~m}) .{ }^{19} \mathrm{~F}\left\{{ }^{1} \mathrm{H}\right\} \mathrm{NMR}\left(\mathrm{CD}_{2} \mathrm{Cl}_{2}, 293 \mathrm{~K}\right): \delta=102.8(10$ lines, $\left.{ }^{1} J_{\mathrm{NbF}}=335 \mathrm{~Hz},[6 \mathrm{~F}],\left[\mathrm{NbF}_{6}\right]^{-}\right) 54.8$ (br m, [4F], cation); $\left(\mathrm{CD}_{2} \mathrm{Cl}_{2}, 243 \mathrm{~K}\right): \delta=102.9$ (10 lines. [6F]), 48.8 (br s, [4F]). ${ }^{31} \mathrm{P}\left\{{ }^{1} \mathrm{H}\right\}$ NMR $\left(\mathrm{CD}_{2} \mathrm{Cl}_{2}, 293 \mathrm{~K}\right): \delta=40.3$ (vbr); (233 K): 41.4 (quintet, $\left.{ }^{2} J_{\mathrm{PF}}=43 \mathrm{~Hz}\right) \cdot{ }^{93} \mathrm{Nb} \mathrm{NMR}\left(\mathrm{CD}_{2} \mathrm{Cl}_{2}, 293 \mathrm{~K}\right): \delta=-1549$ (septet, $\left[\mathrm{NbF}_{6}\right]^{-}$). IR (Nujol)/cm ${ }^{-1}$ : 630 (s br), 602 (s br) (NbF). $\mathrm{UV} / \mathrm{Vis}(\mathrm{dr}) / \mathrm{cm}^{-1}: 27300,33300$.

$\left[\mathrm{TaF}_{4}\left\{\boldsymbol{o}-\mathbf{C}_{6} \mathbf{H}_{4}\left(\mathbf{P M e}_{2}\right)_{2}\right\}_{2}\right]\left[\mathrm{TaF}_{\mathbf{6}}\right]: \mathrm{TaF}_{5}(0.28 \mathrm{~g}, 1.0 \mathrm{mmol})$ was dissolved in anhydrous $\mathrm{MeCN}(10 \mathrm{~mL})$ and $o-\mathrm{C}_{6} \mathrm{H}_{4}\left(\mathrm{PMe}_{2}\right)_{2}$ $(0.20 \mathrm{~g}, 1.0 \mathrm{mmol})$ added. A clear solution formed which was stirred for $1 \mathrm{~h}$, concentrated to $\sim 5 \mathrm{~mL}$ and the precipitate filtered off, rinsed with MeCN (2 mL) and dried in vacuo. White powder. Yield: $0.36 \mathrm{~g}, 75 \%$. Anal: required for $\mathrm{C}_{20} \mathrm{H}_{32} \mathrm{~F}_{10} \mathrm{P}_{4} \mathrm{Ta}_{2}$ (948.3): C, 25.3; H, 3.4. Found: C, 25.2; H, 3.3\%. ${ }^{1} \mathrm{H}$ NMR $\left(\mathrm{CD}_{3} \mathrm{CN}, 295 \mathrm{~K}\right): \delta=1.70(\mathrm{br} \mathrm{s},[12 \mathrm{H}]), 7.79(\mathrm{~s},[2 \mathrm{H}]), 7.92(\mathrm{~s}$, $[2 \mathrm{H}]) ;(243 \mathrm{~K}): 1.68(\mathrm{~s},[12 \mathrm{H}]), 7.77(\mathrm{~s},[2 \mathrm{H}]), 7.92(\mathrm{~s},[2 \mathrm{H}]) .{ }^{19} \mathrm{~F}$ $\left\{{ }^{1} \mathrm{H}\right\} \operatorname{NMR}\left(\mathrm{CD}_{3} \mathrm{CN}, 298 \mathrm{~K}\right): \delta=37.4\left([6 \mathrm{~F}],\left[\mathrm{TaF}_{6}\right]^{-}\right),-39.8$ (quintet, ${ }^{2} J_{\mathrm{PF}}=60 \mathrm{~Hz},[4 \mathrm{~F}]$, cation); (243 K): $38.3(\mathrm{~s},[6 \mathrm{~F}]),-42.3$ $(\mathrm{m},[4 \mathrm{~F}]) .{ }^{31} \mathrm{P}\left\{{ }^{1} \mathrm{H}\right\} \mathrm{NMR}\left(\mathrm{CD}_{3} \mathrm{CN}, 298 \mathrm{~K}\right): \delta=35.4$ (quintet, ${ }^{2} J_{\mathrm{PF}}=$

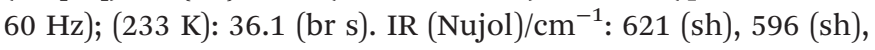
572 (vs) (TaF). UV/Vis (dr)/cm $\mathrm{cm}^{-1}: 33000$.
$\left[\mathbf{T a F}_{4}\left\{\boldsymbol{o}-\mathbf{C}_{6} \mathbf{H}_{4}\left(\mathbf{A s M e}_{2}\right)_{2}\right\}_{2}\right]\left[\mathrm{TaF}_{\mathbf{6}}\right]: \mathrm{TaF}_{5}(0.28 \mathrm{~g}, 1.0 \mathrm{mmol})$ was dissolved in anhydrous MeCN $(10 \mathrm{~mL})$ and $o-\mathrm{C}_{6} \mathrm{H}_{4}\left(\mathrm{AsMe}_{2}\right)_{2}$ (0.29 g, $1.0 \mathrm{mmol}$ ) added. A clear yellow solution formed which deposited a small amount of pale cream precipitate after $\sim 20 \mathrm{~min}$. After stirring for $1 \mathrm{~h}$ the solution was concentrated to $\sim 5 \mathrm{~mL}$, dry diethyl ether $(5 \mathrm{~mL})$ added, and the precipitate filtered off, rinsed with $\mathrm{MeCN}(2 \mathrm{~mL})$ and dried in vacuo. Yellow powder. Yield: $0.40 \mathrm{~g}, 85 \%$. Anal: required for $\mathrm{C}_{20} \mathrm{H}_{32} \mathrm{As}_{4} \mathrm{~F}_{10} \mathrm{Ta}_{2}$ (1124.0): C, 21.4; H, 2.9. Found: C, 21.3; H, 2.8\%. ${ }^{1} \mathrm{H}$ NMR $\left(\mathrm{CD}_{2} \mathrm{Cl}_{2}, 293 \mathrm{~K}\right): \delta=1.63(\mathrm{~s},[12 \mathrm{H}]), 7.59(\mathrm{~s}$, [2H]), 7.64 (s, [2H]); (243 K): 1.60 (s, [12H]), 7.55 (s, [2H]), 7.60 $(\mathrm{s},[2 \mathrm{H}]) .{ }^{19} \mathrm{~F}\left\{{ }^{1} \mathrm{H}\right\} \operatorname{NMR}\left(\mathrm{CD}_{2} \mathrm{Cl}_{2}, 293 \mathrm{~K}\right): \delta=39.5(\mathrm{~s},[6 \mathrm{~F}]$, $\left.\left[\mathrm{TaF}_{6}\right]^{-}\right),-28.0$ (s, [4F], cation); (243 K): 39.7 (s, [6F]), -29.0 (s, [4F]). IR (Nujol)/cm ${ }^{-1}: 616$ (sh), 578 (br) (TaF). UV/Vis (dr)/ $\mathrm{cm}^{-1}$ : 23400 (sh), $27000,30600$.

$\left[\mathbf{T a F}_{4}\left\{\mathbf{M e}_{2} \mathbf{P}\left(\mathbf{C H}_{2}\right)_{2} \mathbf{P M e}_{2}\right\}_{2}\right]\left[\mathbf{T a F}_{6}\right]$ : was made similarly to the niobium analogue. White microcrystalline solid. Yield: $83 \%$. Anal: required for $\mathrm{C}_{12} \mathrm{H}_{32} \mathrm{~F}_{10} \mathrm{P}_{4} \mathrm{Ta}_{2}$ (852.2): $\mathrm{C}, 16.9 ; \mathrm{H}, 3.8$. Found: $\mathrm{C}, 16.8 ; \mathrm{H}, 3.8 \% .{ }^{1} \mathrm{H}$ NMR $\left(\mathrm{CD}_{3} \mathrm{CN}, 293 \mathrm{~K}\right): \delta=1.81(\mathrm{~s}$, $[12 \mathrm{H}]), 2.10(\mathrm{~s},[4 \mathrm{H}]) ;(233 \mathrm{~K}): 1.82(\mathrm{~s},[12 \mathrm{H}]), 2.10(\mathrm{~s},[4 \mathrm{H}])$. ${ }^{19} \mathrm{~F}\left\{{ }^{1} \mathrm{H}\right\} \operatorname{NMR}\left(\mathrm{CD}_{3} \mathrm{CN}, 293 \mathrm{~K}\right): \delta=38.3\left(\mathrm{~s},[6 \mathrm{~F}],\left[\mathrm{TaF}_{6}\right]^{-}\right),-40.8$ (quintet, ${ }^{2} J_{\mathrm{PF}}=60 \mathrm{~Hz}$, cation); $\left(\mathrm{CD}_{3} \mathrm{CN}, 243 \mathrm{~K}\right): 38.8$ (s, [6F]), -43.6 (quintet, [4F]). ${ }^{31} \mathrm{P}\left\{{ }^{1} \mathrm{H}\right\}$ NMR $\left(\mathrm{CD}_{3} \mathrm{CN}, 293 \mathrm{~K}\right): \delta=36.9$ (quintet, ${ }^{2} J_{\mathrm{PF}}=60 \mathrm{~Hz}$ ); (233 K): 37.9 (quintet). IR (Nujol) $/ \mathrm{cm}^{-1}$ : 613 (sh), 575 (vbr, s) (TaF). UV/Vis (dr)/ $/ \mathrm{cm}^{-1}: 33400$.

$\left[\mathbf{T a F}_{4}\left\{\mathbf{E t}_{\mathbf{2}} \mathbf{P}\left(\mathbf{C H}_{2}\right)_{2} \mathbf{P E t}_{2}\right\}_{2}\right]\left[\mathbf{T a F}_{\mathbf{6}}\right]$ : was made similarly to the niobium analogue. White waxy solid. Yield: $65 \%$. ${ }^{1} \mathrm{H}$ NMR $\left(\mathrm{CD}_{3} \mathrm{CN}, 293 \mathrm{~K}\right): \delta=1.17$ (br s, [12H]), 1.80 (br s, [8H]), 2.15 (s, $[4 \mathrm{H}]) ;(233 \mathrm{~K}): 1.08(\mathrm{~s},[12 \mathrm{H}]), 1.84(\mathrm{~s},[8 \mathrm{H}]), 2.12(\mathrm{~s}[4 \mathrm{H}]) \cdot{ }^{19} \mathrm{~F}$ $\left\{{ }^{1} \mathrm{H}\right\}$ NMR $\left(\mathrm{CD}_{3} \mathrm{CN}, 293 \mathrm{~K}\right): \delta=38.8\left(\mathrm{~s},[6 \mathrm{~F}],\left[\mathrm{TaF}_{6}\right]^{-}\right),-25.7$ (quintet, ${ }^{2} J_{\mathrm{PF}}=55 \mathrm{~Hz},[4 \mathrm{~F}]$, cation); $\left(\mathrm{CD}_{3} \mathrm{CN}, 243 \mathrm{~K}\right): 38.9(\mathrm{~s}$, [6F]), -28.8 (quintet, [4F]). ${ }^{31} \mathrm{P}\left\{{ }^{1} \mathrm{H}\right\}$ NMR ( $\left.\mathrm{CD}_{3} \mathrm{CN}, 293 \mathrm{~K}\right): \delta=$ 45.0 (quintet, ${ }^{2} J_{\mathrm{PF}}=55 \mathrm{~Hz}$ ); (233 K): 45.3 (quintet). IR (Nujol)/ $\mathrm{cm}^{-1}: 615$ (sh), 587 (vbr, s) (TaF). UV/Vis (dr)/cm ${ }^{-1}: 33800$.

$\left[\mathbf{T a F}_{4}\left\{\boldsymbol{o}-\mathbf{C}_{6} \mathbf{H}_{4}\left(\mathbf{P P h}_{2}\right)_{2}\right\}_{2}\right]\left[\mathbf{T a F}_{6}\right]$ : was made similarly to the niobium analogue using $o-\mathrm{C}_{6} \mathrm{H}_{4}\left(\mathrm{PPh}_{2}\right)_{2}(0.40 \mathrm{~g}, 0.9 \mathrm{mmol})$ and $\mathrm{TaF}_{5}$ (0.26 g, $\left.0.9 \mathrm{mmol}\right)$. Yield: $0.48 \mathrm{~g}, 73 \%$. Anal: required for $\mathrm{C}_{60} \mathrm{H}_{48} \mathrm{~F}_{10} \mathrm{P}_{4} \mathrm{Ta}_{2}$ (1444.8): C, 49.9; H, 3.6. Found: C, 49.8; H, $3.5 \%$. ${ }^{1} \mathrm{H}$ NMR $\left(\mathrm{CD}_{2} \mathrm{Cl}_{2}, 293 \mathrm{~K}\right): \delta=7.77-7.23(\mathrm{~m}) .{ }^{19} \mathrm{~F}\left\{{ }^{1} \mathrm{H}\right\}$ $\operatorname{NMR}\left(\mathrm{CD}_{2} \mathrm{Cl}_{2}, 293 \mathrm{~K}\right): \delta=38.6\left(\mathrm{~s},[6 \mathrm{~F}],\left[\mathrm{TaF}_{6}\right]^{-}\right), 16.8$ (quintet, ${ }^{2} J_{\mathrm{PF}}=57 \mathrm{~Hz}$, cation); (243 K): $\delta=38.7$ (s), 12.3 (br s). ${ }^{31} \mathrm{P}\left\{{ }^{1} \mathrm{H}\right\}$ NMR $\left(\mathrm{CD}_{2} \mathrm{Cl}_{2}, 293 \mathrm{~K}\right): \delta=38.6$ (br); (233 K): 39.0 (quintet, ${ }^{2} J_{\mathrm{PF}}=57 \mathrm{~Hz}$ ). IR (Nujol) $/ \mathrm{cm}^{-1} 583$ (s, br), 545 (s, br) (TaF). UV/ Vis $(\mathrm{dr}) / \mathrm{cm}^{-1}: 30300,33000$.

$\left[\mathbf{N b C l}_{\mathbf{4}}\left\{\boldsymbol{o}-\mathbf{C}_{\mathbf{6}} \mathbf{H}_{\mathbf{4}}\left(\mathbf{A s M e}_{2}\right)_{2}\right\}_{2}\right]\left[\mathbf{N b C l}_{\mathbf{6}}\right]:$ Made as described. ${ }^{16}$ Orange-red powder. ${ }^{1} \mathrm{H}$ NMR $\left(\mathrm{CD}_{2} \mathrm{Cl}_{2}, 293 \mathrm{~K}\right): \delta=1.92$ (s, $[12 \mathrm{H}]), 7.78(\mathrm{~s},[2 \mathrm{H}]), 7.90(\mathrm{~s},[2 \mathrm{H}]) .{ }^{93} \mathrm{Nb} \mathrm{NMR}\left(\mathrm{CD}_{2} \mathrm{Cl}_{2}, 293 \mathrm{~K}\right)$ : $\delta=+6.2\left(\mathrm{~s},\left[\mathrm{NbCl}_{6}\right]^{-}\right)$. IR (Nujol)/ $/ \mathrm{cm}^{-1}: 324$ (vs) (NbCl). UV/Vis $(\mathrm{dr}) / \mathrm{cm}^{-1}: 20350,29760$.

$\left[\mathbf{T a C l}_{4}\left\{\boldsymbol{o}-\mathbf{C}_{6} \mathbf{H}_{\mathbf{4}}\left(\mathbf{A s M e}_{2}\right)_{2}\right\}_{2}\right]\left[\mathbf{T a C l}_{\mathbf{6}}\right]$ : Made as described. ${ }^{16}$ Deep yellow powder. ${ }^{1} \mathrm{H}$ NMR $\left(\mathrm{CD}_{2} \mathrm{Cl}_{2}, 293 \mathrm{~K}\right): \delta=2.00(\mathrm{~s},[12 \mathrm{H}])$, 7.80 (s, [2H]), 7.86 (s, [2H]). IR (Nujol)/ $\mathrm{cm}^{-1} 323$ (vs), 303 (s) (TaCl). UV/Vis (dr) $/ \mathrm{cm}^{-1}: 23$ 530, 31250.

$\left[\mathbf{N b C l}_{4}\left\{\boldsymbol{o}-\mathbf{C}_{6} \mathbf{H}_{4}\left(\mathbf{P M e}_{2}\right)_{2}\right\}_{2}\right] \mathbf{C l}: \mathrm{NbCl}_{5}(0.135 \mathrm{~g}, 0.50 \mathrm{mmol})$ was dissolved in acetonitrile $(5 \mathrm{~mL})$ whilst stirring giving a bright yellow-green solution. $o-\mathrm{C}_{6} \mathrm{H}_{4}\left(\mathrm{PMe}_{2}\right)_{2}(0.20 \mathrm{~g}, 1.0 \mathrm{mmol})$ was 
added slowly to the solution, which resulted in rapid formation of a red-brown precipitate. The reaction was left to stir another $10 \mathrm{~min}$. The solution was filtered, the precipitate was washed with small amount of dichloromethane and dried in vacuo. Yield: $0.280 \mathrm{~g}, 83 \%$. Red-orange single crystals of $\left[\mathrm{NbCl}_{4}\left(o-\mathrm{C}_{6} \mathrm{H}_{4}\left(\mathrm{PMe}_{2}\right)_{2}\right)_{2}\right] \mathrm{Cl}$ were grown from a saturated dichloromethane solution cooled in the freezer. Anal: required for $\mathrm{C}_{20} \mathrm{H}_{32} \mathrm{Cl}_{5} \mathrm{NbP}_{4}$ (666.5): C, 36.0; $\mathrm{H}, 4.8$. Found: $\mathrm{C}, 35.9 ; \mathrm{H}$, 4.7\%. ${ }^{1} \mathrm{H}$ NMR $\left(\mathrm{CD}_{2} \mathrm{Cl}_{2}, 295 \mathrm{~K}\right): \delta=1.96$ (s, [12H]), 7.70-7.62 (m, [4H]). ${ }^{31} \mathrm{P}\left\{{ }^{1} \mathrm{H}\right\}$ NMR $\left(\mathrm{CH}_{2} \mathrm{Cl}_{2}-\mathrm{CD}_{2} \mathrm{Cl}_{2}, 298 \mathrm{~K}\right): \delta=58.4(\mathrm{~s}) . \mathrm{IR}$ (Nujol)/ $\mathrm{cm}^{-1}: 320$ (s), 293 (s) (NbCl). UV/Vis (dr)/ $\mathrm{cm}^{-1}: 23000$, 34500.

$\left[\mathbf{N b C l}_{4}\left\{\mathbf{M e}_{2} \mathbf{P}\left(\mathbf{C H}_{2}\right)_{2} \mathbf{P M e}_{2}\right\}_{2}\right]\left[\mathbf{N b C l}_{6}\right]: \quad \mathrm{NbCl}_{5} \quad(0.135 \quad \mathrm{~g}$, $0.50 \mathrm{mmol}$ ) was dissolved in acetonitrile $(5 \mathrm{~mL})$ whilst stirring giving a bright yellow-green solution. $\mathrm{Me}_{2} \mathrm{P}\left(\mathrm{CH}_{2}\right)_{2} \mathrm{PMe}_{2}$ $(0.075 \mathrm{~g}, 0.50 \mathrm{mmol})$ in $3 \mathrm{~mL}$ acetonitrile was added to the solution which resulted in rapid formation of red-brown precipitate. The reaction was left to stir $10 \mathrm{~min}$. The solution was filtered, the precipitate washed with small amount of dichloromethane and dried in vacuo. Yield: $0.130 \mathrm{~g}, 65 \%$. Anal: required for $\mathrm{C}_{12} \mathrm{H}_{32} \mathrm{Cl}_{10} \mathrm{Nb}_{2} \mathrm{P}_{4}$ (840.6): $\mathrm{C}, 17.1 ; \mathrm{H}, 3.8$. Found: $\mathrm{C}, 17.3 ; \mathrm{H}, 3.9 \% .{ }^{1} \mathrm{H} \mathrm{NMR}\left(\mathrm{CD}_{2} \mathrm{Cl}_{2}, 293 \mathrm{~K}\right): \delta=1.73$ (br s, [12H]), 2.01 (br, [4H]). ${ }^{31} \mathrm{P}\left\{{ }^{1} \mathrm{H}\right\}$ NMR $\left(\mathrm{CH}_{2} \mathrm{Cl}_{2}-\mathrm{CD}_{2} \mathrm{Cl}_{2}, 298 \mathrm{~K}\right)$ : $\delta=56.3(\mathrm{~s}) .{ }^{93} \mathrm{Nb} \mathrm{NMR}\left(\mathrm{CH}_{2} \mathrm{Cl}_{2}-\mathrm{CD}_{2} \mathrm{Cl}_{2}, 298 \mathrm{~K}\right): \delta=6.1(\mathrm{~s}) . \mathrm{IR}$ (Nujol) $/ \mathrm{cm}^{-1}: 303$ (s, vbr) (NbCl). UV/Vis (dr) $/ \mathrm{cm}^{-1}: 25980$, 32330.

$\left[\mathbf{T a C l}_{4}\left\{\boldsymbol{o}-\mathbf{C}_{6} \mathbf{H}_{4}\left(\mathbf{P M e}_{2}\right)_{2}\right\}_{2}\right]\left[\mathbf{T a C l}_{6}\right]:$ To a suspension of $\mathrm{TaCl}_{5}$ $(0.090 \mathrm{~g}, 0.25 \mathrm{mmol})$ in acetonitrile $(5 \mathrm{~mL})$ was added $o-\mathrm{C}_{6} \mathrm{H}_{4}\left(\mathrm{PMe}_{2}\right)_{2}(0.050 \mathrm{~g}, 0.25 \mathrm{mmol})$ with stirring which resulted in a formation of a white precipitate. The reaction was left to stir for $30 \mathrm{~min}$, and then filtered. The white solid was washed with small amount of dichloromethane and dried. Yield: $0.10 \mathrm{~g}, 66 \%$. Anal: required for $\mathrm{C}_{20} \mathrm{H}_{32} \mathrm{Cl}_{10} \mathrm{P}_{4} \mathrm{Ta}_{2}$ (1112.8): C, 21.6; H, 2.9. Found: C, 21.6; H, 3.0\%. ${ }^{1} \mathrm{H}$ NMR $\left(\mathrm{CD}_{2} \mathrm{Cl}_{2}, 295 \mathrm{~K}\right)$ : $\delta=1.71$ (s, [12H]), $7.75(\mathrm{br},[4 \mathrm{H}]) .{ }^{31} \mathrm{P}\left\{{ }^{1} \mathrm{H}\right\} \quad \mathrm{NMR} \mathrm{CH}_{2} \mathrm{Cl}_{2}-$ $\mathrm{CD}_{2} \mathrm{Cl}_{2}, 298 \mathrm{~K}$ ): $\delta=44.6$ (br s). IR (Nujol/cm ${ }^{-1}$ ): 324 (s), 279 (s) (TaCl). UV/Vis (dr)/ $\mathrm{cm}^{-1}: 27550,31250$.

$\left[\mathrm{NbCl}_{4}\left\{o-\mathrm{C}_{6} \mathrm{H}_{4}\left(\mathrm{PMe}_{2}\right)_{2}\right\}_{2}\right]\left[\mathrm{NbOCl}_{4}\left(\mathrm{CH}_{3} \mathrm{CN}\right)\right]$ and $\left[\left\{o-\mathrm{C}_{6} \mathrm{H}_{4}-\right.\right.$ $\left.\left.\left(\mathrm{PMe}_{2}\right)_{2}\right\} \mathrm{NbOCl}_{3}(\boldsymbol{\mu}-\mathrm{O}) \mathbf{N b C l}_{3}\left(\mathrm{CH}_{3} \mathrm{CN}\right)\left\{\boldsymbol{o}-\mathrm{C}_{6} \mathbf{H}_{4}\left(\mathrm{PMe}_{2}\right)_{2}\right\}\right]: \quad \mathrm{NbCl}_{5}$ $(0.135 \mathrm{~g}, 0.50 \mathrm{mmol})$ was dissolved in acetonitrile $(5 \mathrm{~mL})$ giving a bright yellow-green solution. HMDSO $(0.10 \mathrm{~g}$, $0.60 \mathrm{mmol}$ ) was added. The mixture was left to stir under nitrogen for $30 \mathrm{~min}$ during which time the solution turned very pale yellow. $o-\mathrm{C}_{6} \mathrm{H}_{4}\left(\mathrm{PMe}_{2}\right)_{2}(0.10 \mathrm{~g}, 0.50 \mathrm{mmol})$ in $3 \mathrm{~mL}$ acetonitrile was added slowly to the solution which resulted in formation of white precipitate immediately with a solution colour change to red-orange. The reaction was left to stir for another $5 \mathrm{~min}$ and then the white precipitate filtered off. The filtrate was refrigerated for several days to give red-orange crystals of $\left[\mathrm{NbCl}_{4}\left\{0-\mathrm{C}_{6} \mathrm{H}_{4}\left(\mathrm{PMe}_{2}\right)_{2}\right\}_{2}\right]\left[\mathrm{NbOCl}_{4}\left(\mathrm{CH}_{3} \mathrm{CN}\right)\right]$ Yield: $0.023 \mathrm{~g}, 10 \%$. Anal: required for $\mathrm{C}_{22} \mathrm{H}_{35} \mathrm{Cl}_{8} \mathrm{NNb}_{2} \mathrm{OP}_{4}$ (922.8): C, 28.6; H, 3.8; N, 1.5. Found: C, 28.6; H, 3.8; N, 1.6. ${ }^{1} \mathrm{H}$ NMR $\left(\mathrm{CD}_{2} \mathrm{Cl}_{2}, 295 \mathrm{~K}\right): \delta=1.98(\mathrm{~s},[3 \mathrm{H}], \mathrm{MeCN}), 2.11(\mathrm{~s},[24 \mathrm{H}])$, 7.73-7.87 (m, [8H], aromatic H). ${ }^{31} \mathrm{P}\left\{{ }^{1} \mathrm{H}\right\} \mathrm{NMR}\left(\mathrm{CH}_{2} \mathrm{Cl}_{2}-\mathrm{CDCl}_{3}\right.$, $298 \mathrm{~K}): \delta=55.2(\mathrm{~s})$. IR (Nujol $/ \mathrm{cm}^{-1}$ ): 2305 (vw), 2279 (vw) (MeCN), 947 (s, NbO), 320 (vbr), 289 (s) (NbCl). The white pre- cipitate was washed with small amount of dichloromethane and dried. Colourless single crystals of $\left[\left\{o-\mathrm{C}_{6} \mathrm{H}_{4}\left(\mathrm{PMe}_{2}\right)_{2}\right\}-\right.$ $\left.\mathrm{NbOCl}_{3}(\mu-\mathrm{O}) \mathrm{NbCl}_{3}\left(\mathrm{CH}_{3} \mathrm{CN}\right)\left\{o-\mathrm{C}_{6} \mathrm{H}_{4}\left(\mathrm{PMe}_{2}\right)_{2}\right\}\right]$ were grown from a saturated dichloromethane solution in the freezer. Yield: $0.045 \mathrm{~g}, 12 \%$. Anal: required for $\mathrm{C}_{22} \mathrm{H}_{35} \mathrm{Cl}_{6} \mathrm{NNb}_{2} \mathrm{O}_{3} \mathrm{P}_{4}$ (884.0): C, 29.9; H, 4.0, N, 1.6. Found: C, 30.5; H, 3.9; N, 1.6. ${ }^{1} \mathrm{H}$ NMR $\left(\mathrm{CD}_{2} \mathrm{Cl}_{2}, 295 \mathrm{~K}\right): \delta=1.58\left(\mathrm{~s},[6 \mathrm{H}], \mathrm{PMe}_{2}\right), 1.62\left(\mathrm{~s},[12 \mathrm{H}], \mathrm{PMe}_{2}\right)$, 1.77 (s, [6H], $\mathrm{PMe}_{2}$ ), 1.98 (s, [3H], MeCN), 7.57-7.68 (m, [8H]). ${ }^{31} \mathrm{P}\left\{{ }_{1}^{1} \mathrm{H}\right\}$ NMR $\left(\mathrm{CH}_{2} \mathrm{Cl}_{2}-\mathrm{CDCl}_{3}, 298 \mathrm{~K}\right): \delta=42.9(\mathrm{~s},[\mathrm{P}]), 38.3(\mathrm{br}$, [2P]), 36.4 (s, [P]). IR (Nujol/ $\left.\mathrm{cm}^{-1}\right)$ : 943 (s, NbO), 824(s) (Nb-O$\mathrm{Nb}), 355,304(\mathrm{~s}, \mathrm{NbCl})$.

$\left[\left(\left\{\mathbf{M e}_{2} \mathbf{P}\left(\mathbf{C H}_{2}\right)_{2} \mathbf{P M e}_{2}\right\} \mathbf{N b O C l}_{3}\right)_{2}\left(\boldsymbol{\mu}-\mathbf{M e}_{2} \mathbf{P}\left(\mathbf{C H}_{2}\right)_{2} \mathbf{P M e}_{2}\right)\right]: \quad \mathrm{NbCl}_{5}$ $(0.135 \mathrm{~g}, 0.50 \mathrm{mmol})$ was dissolved in acetonitrile $(5 \mathrm{~mL})$ whilst stirring giving a bright yellow-green solution. HMDSO $(0.10 \mathrm{~g}, 0.60 \mathrm{mmol})$ was added. The mixture was left to stir under nitrogen for 30 min during which time the solution turned very pale yellow. $\mathrm{Me}_{2} \mathrm{P}\left(\mathrm{CH}_{2}\right)_{2} \mathrm{PMe}_{2}(0.075 \mathrm{~g}, 0.50 \mathrm{mmol})$ in $5 \mathrm{~mL}$ of dichloromethane was added to the solution which resulted in formation of white precipitate immediately. The reaction was left to stir another $10 \mathrm{~min}$ and then filtered. The precipitate was washed with a small amount of dichloromethane and dried in vacuo. Yield: $0.088 \mathrm{~g}, 76 \%$. Colourless single crystals of $\left[\left\{\mathrm{Me}_{2} \mathrm{P}\left(\mathrm{CH}_{2}\right)_{2} \mathrm{PMe}_{2}\right\} \mathrm{NbOCl}_{3}\right\}_{2}\left(\mu-\mathrm{Me}_{2} \mathrm{P}-\right.$ $\left.\left.\left(\mathrm{CH}_{2}\right)_{2} \mathrm{PMe}_{2}\right)\right]$ were grown from saturated dichloromethane solution in the freezer. Anal: required for $\mathrm{C}_{18} \mathrm{H}_{48} \mathrm{Cl}_{6} \mathrm{Nb}_{2} \mathrm{O}_{2} \mathrm{P}_{6}$ (880.9): C, 24.5; H, 5.5. Found: C, 24.5; H, 5.5\%. ${ }^{1} \mathrm{H}$ NMR $\left(\mathrm{CD}_{2} \mathrm{Cl}_{2}, 295 \mathrm{~K}\right): \delta=1.52\left(\mathrm{~s},[12 \mathrm{H}], \mathrm{PMe}_{2}\right), 1.77\left(\mathrm{~s},[24 \mathrm{H}], \mathrm{PMe}_{2}\right)$, 2.14-2.38 (m, [12H], $\left.\mathrm{CH}_{2}\right) .{ }^{31} \mathrm{P}\left\{{ }^{1} \mathrm{H}\right\} \quad \mathrm{NMR} \quad \mathrm{CH}_{2} \mathrm{Cl}_{2}-\mathrm{CD}_{2} \mathrm{Cl}_{2}$, $298 \mathrm{~K}): \delta=33.3$ (s, [4P]), 0.7 (s, [2P]). IR (Nujol)/ $/ \mathrm{cm}^{-1}: 939(\mathrm{~m}$, $\mathrm{NbO}), 321(\mathrm{w}), 288(\mathrm{~m})(\mathrm{NbCl})$.

\section{X-ray experimental}

Details of the crystallographic data collection and refinement parameters are given in Table 1. Crystals suitable for single crystal X-ray analysis were obtained as described above. Data collections used a Rigaku AFC12 goniometer equipped with an enhanced sensitivity (HG) Saturn724+ detector mounted at the window of an FR-E+ SuperBright molybdenum $(\lambda=0.71073 \AA)$ rotating anode generator with VHF Varimax optics $(70 \mu \mathrm{m}$ focus) with the crystal held at $100 \mathrm{~K}\left(\mathrm{~N}_{2}\right.$ cryostream). Structure solution and refinements were performed with either SHELX $(\mathrm{S} / \mathrm{L}) 97$ or SHELX(S/L)2013 ${ }^{28}$ and were straightforward except as detailed below. $\mathrm{H}$ atoms bonded to $\mathrm{C}$ were placed in calculated positions using the default $\mathrm{C}-\mathrm{H}$ distance and refined using a riding model. The anion in $\left[\mathrm{NbF}_{4}\left\{0-\mathrm{C}_{6} \mathrm{H}_{4}\left(\mathrm{AsMe}_{2}\right)_{2}\right\}_{2}\right]-$ $\left[\mathrm{NbF}_{6}\right]$ was disordered which was satisfactorily modeled with a number of partially occupied $\mathrm{F}$ positions and thermal parameter restraints. The $\left[\left\{o-\mathrm{C}_{6} \mathrm{H}_{4}\left(\mathrm{PMe}_{2}\right)_{2}\right\} \mathrm{NbOCl}_{3}-\mu-\right.$ $\left.\mathrm{O}-\mathrm{NbCl}_{3}\left(\mathrm{CH}_{3} \mathrm{CN}\right)\left\{0-\mathrm{C}_{6} \mathrm{H}_{4}\left(\mathrm{PMe}_{2}\right)_{2}\right\}\right]$ crystals were weakly diffracting with poorly defined reflection profiles and it was necessary to employ global restraints to the atomic displacement parameters. The apical chlorine and oxygen atoms coordinated to $\mathrm{Nb} 2$ are modeled as disordered ( $c a .80 / 20$ ) over the 2 positions using thermal parameter constraints and distance restraints $(\mathrm{Nb}-\mathrm{Cl}=2.47, \mathrm{Nb}-\mathrm{O} 1.8)$. 


\section{Acknowledgements}

This work was funded by EPSRC (through a Programme Grant EP/I033394/1 and also through EP/I010890/1). The SCFED Project (http://www.scfed.net) is a multidisciplinary collaboration of British universities investigating the fundamental and applied aspects of supercritical fluids.

\section{References}

1 A. J. Edwards, J. Chem. Soc., 1964, 3714.

2 T. A. O'Donnell, in Advanced Inorganic Fluorides, ed. T. Nakajima, B. Zemva and A. Tressaud, Elsevier, Amsterdam, 2000, ch. 11.

3 S. L. Benjamin, W. Levason and G. Reid, Chem. Soc. Rev., 2013, 42, 1460.

4 (a) F. Marchetti and G. Pampaloni, Chem. Commun., 2012, 48, 635; (b) R. Bini, C. Chiappe, F. Marchetti, G. Pampaloni and S. Zacchini, Inorg. Chem., 2010, 49, 339; (c) F. Marchetti, G. Pampaloni and S. Zacchini, Inorg. Chem., 2008, 47, 365; (d) F. Marchetti, G. Pampaloni and S. Zacchini, J. Fluorine Chem., 2010, 131, 21; (e) F. Marchetti, G. Pampaloni and S. Zacchini, Dalton Trans., 2009, 8096; (f) F. Marchetti, G. Pampaloni and S. Zacchini, Dalton Trans., 2009, 6759; $(g)$ M. Bortoluzzi, F. Marchetti, G. Pampaloni, M. Pucino and S. Zacchini, Dalton Trans., 2013, 42, 13054; (h) J. A. S. Howell and K. C. Moss, J. Chem. Soc. A, 1971, 2483.

5 W. Levason, G. Reid, J. Trayer and W. Zhang, Dalton Trans., 2014, 43, 3649.

6 (a) M. Jura, W. Levason, R. Ratnani, G. Reid and M. Webster, Dalton Trans., 2010, 39, 883; (b) M. Jura, W. Levason, G. Reid and M. Webster, Dalton Trans., 2009, 7610.

7 S. L. Benjamin, A. Hyslop, W. Levason and G. Reid, J. Fluorine Chem., 2012, 137, 77.

8 L. G. Hubert-Pfalzgraf, M. Postel and J. G. Reiss, Comprehensive Coordination Chemistry, ed. G. Wilkinson, R. D. Gillard and J. A. McCleverty, Pergamon, Oxford, 1987, 3,585 .

9 S. L. Benjamin, A. Hyslop, W. Levason and M. Webster, Acta Crystallogr., Sect. C: Cryst. Struct. Commun., 2011, 67, $\mathrm{m} 221$.
10 M. Jura, W. Levason, E. Petts, G. Reid, M. Webster and W. Zhang, Dalton Trans., 2010, 39, 10264.

11 F. A. Cotton, L. R. Falvello and R. C. Najar, Inorg. Chem., 1983, 32, 770.

12 G. C. Allen and K. D. Warren, Struct. Bonding, 1974, 19, 105.

13 M. Valloton and A. E. Merbach, Helv. Chim. Acta, 1974, 57, 254.

14 M. F. Davis, W. Levason, G. Reid and M. Webster, Dalton Trans., 2008, 2261.

15 M. F. Davis, M. Clarke, W. Levason, G. Reid and M. Webster, Eur. J. Inorg. Chem., 2006, 2773.

16 R. J. H. Clark, D. L. Kepert and R. S. Nyholm, J. Chem. Soc., 1965, 2877.

17 J. C. Dewan, D. L. Kepert, C. L. Raston and A. H. White, J. Chem. Soc., Dalton Trans., 1975, 2031.

18 A. B. P. Lever, Inorganic Electronic Spectroscopy, Elsevier, Amsterdam, $2^{\text {nd }}$ edn, 1984.

19 S. L. Benjamin, W. Levason, D. Pugh, G. Reid and W. Zhang, Dalton Trans., 2012, 41, 12548.

20 V. C. Gibson, T. P. Kee, R. M. Sorrell, A. P. Bashall and M. McPartlin, Polyhedron, 1988, 7, 2221.

21 V. C. Gibson and T. P. Kee, J. Chem. Soc., Dalton Trans., 1993, 1657.

22 P. E. Garrou, Chem. Rev., 1985, 85, 171.

23 W. Keim, P. Kraneburg, G. Dahmen, G. Deckers, U. Englert, K. Linn, T. P. Spaniol, G. Raabe and C. Kriiger, Organometallics, 1994, 13, 3085.

24 (a) R. Hart, W. Levason, B. Patel and G. Reid, J. Chem. Soc., Dalton Trans., 2002, 3153; (b) W. Levason, B. Patel and G. Reid, Inorg. Chim. Acta, 2004, 357, 2115; (c) W. Levason, M. L. Matthews, B. Patel, G. Reid and M. Webster, Dalton Trans., 2004, 3305.

25 (a) W. Levason, B. Patel, G. Reid, V.-A. Tolhurst and M. Webster, J. Chem. Soc., Dalton Trans., 2000, 3001. R. Hart, W. Levason, B. Patel and G. Reid, Eur. J. Inorg. Chem., 2001, 2927.

26 R. D. Feltham, A. Kasenally and R. S. Nyholm, J. Organomet. Chem., 1967, 7, 285.

27 E. P. Kyba, S. T. Liu and R. L. Harris, Organometallics, 1983, 2, 1877.

28 G. M. Sheldrick, Acta Crystallogr., Sect. A: Fundam. Crystallogr., 2008, 64, 112. 